\title{
Including maintenance in life cycle assessment of road and rail infrastructure-a literature review
}

\author{
Carolina Liljenström ${ }^{1}$ (1) $\cdot$ Anna Björklund ${ }^{1} \cdot$ Susanna Toller ${ }^{2}$
}

Received: 15 March 2021 / Accepted: 30 November 2021 / Published online: 24 January 2022

(c) The Author(s) 2021

\begin{abstract}
Purpose LCA is increasingly used in infrastructure policy and planning. This study maps approaches used in comparative LCA of road and rail infrastructure to (1) determine the length of the analysis period, (2) estimate the maintenance frequency, and (3) include the effects of climate change on infrastructure performance. A LCA may need to fulfil different requirements in different decision-contexts. The relevance of the approaches for decision-making in policy and procurement is therefore discussed.

Methods Ninety-two comparative LCAs of road and rail infrastructure published in peer-reviewed journals January 2016July 2020 were reviewed. Papers were found through a systematic process of searching electronic databases, applying inclusion criteria, and conducting backward and forward snowballing.

Results and discussion The analysis period was commonly determined based on infrastructure service life. The maintenance frequency was estimated based on current practice, laboratory tests, modelling, or scenarios. The effects of climate change were considered in two papers by comparing results in a control case and in a changed climate. In policy and procurement, current practice approaches are not adapted to innovative solutions or to climate change. Modelling and laboratory tests could improve calculations of the maintenance phase but might have some limitations related to innovative solutions. Scenarios could be readily applied in a policy context; however, in procurement, consistent and generic scenarios should be used.

Conclusions Results suggest what approaches could be used to account for maintenance in infrastructure LCA depending on the decision-context. The LCA community is suggested to research other approaches than current practice to account for long analysis periods, climate change, and innovative solutions. Additionally, literature not covered here could be reviewed for additional approaches and perspectives. Examples include stand-alone LCAs, method development papers, papers on the individual approaches and decision-contexts, certification systems, standards, and guidelines.
\end{abstract}

Keywords Life cycle assessment $\cdot$ Infrastructure $\cdot$ Road $\cdot$ Rail $\cdot$ Maintenance $\cdot$ Review $\cdot$ Procurement $\cdot$ Policy

\section{Introduction}

Communicated by Xin Sun

Carolina Liljenström

carlil@kth.se

Anna Björklund

anna.bjorklund@abe.kth.se

Susanna Toller

susanna.toller@trafikverket.se

1 School of Architecture and the Built Environment, Department of Sustainable Development, Environmental Science and Engineering, KTH Royal Institute of Technology, Stockholm, Sweden

2 Swedish Transport Administration, Solna, Sweden
Since the 1990s, life cycle assessment (LCA) has been conducted to assess the environmental impacts of road and rail infrastructure (Santero et al. 2011a; Olugbenga et al. 2019). The LCAs cover a variety of infrastructure forms, including surface roads, tunnels, and bridges as well as ancillary components such as crash barriers. Many of the infrastructure LCAs aim to compare different construction solutions or construction materials to determine which alternative has the lowest environmental impacts from a life cycle perspective.

More recently, LCA has become increasingly used as strategic decision-support within infrastructure policy and planning, for example in procurement (Saxe and Kasraian 2020). As decision-support, LCA can be conducted at different 
decision-levels: the network level and the project level. At the project level, a LCA is conducted for a single construction project, whereas a LCA at the network level is conducted for several construction projects (Butt et al. 2015). LCA can be used throughout the planning of infrastructure projects, from early planning (such as choice of road location) to late planning (such as choice of design) (ibid.). The implementation of LCA in procurement is an example of a project level LCA conducted in late planning (Butt et al. 2015). In practice, several countries have implemented, or plan to implement, LCA in infrastructure procurement. Examples include Sweden (Toller and Larsson 2017), Canada (Future Cities Canada 2018), The Netherlands (Keijzer et al. 2015), and Belgium (Anthonissen et al. 2016).

In a LCA, the life cycle of infrastructure is commonly divided into five stages: material production, construction, maintenance, operation, and end-of-life. This study focuses on the maintenance stage. An infrastructure project has a long service life and, to maintain its functionality, it requires maintenance for many years to come. The maintenance activities contribute to the total life cycle impacts of a project. Liljenström et al. (2019) found that maintenance (including reinvestment) of Swedish infrastructure contributes more to the annual climate impact than new construction, showing that impacts from infrastructure maintenance must also be reduced.

The environmental impacts of maintenance could be affected in the design stage by designing infrastructure with low maintenance related impacts. For example, LCAs comparing construction solutions have found that the material with highest production related impacts might have lower life cycle impacts due to reduced maintenance needs and longer service life (see for example Penadés-Plà et al. (2017)). However, the assessment of maintenance related impacts in LCA is uncertain due to data uncertainty, methodological uncertainty, and uncertainty about the future per se.

One uncertain aspect in infrastructure LCA, which influences the quantified impacts of maintenance, is the length of the analysis period. The analysis period corresponds to "the time period over which the functional unit is evaluated" (Santero et al. 2011b), i.e. for how many years into the future that maintenance activities are considered. There is no standardised way to select analysis period in infrastructure LCA. Although the analysis period could be based on the infrastructure service life, infrastructure is long-lived without a well-defined end-of-life, and hence, the service life can be difficult to determine (Saxe and Kasraian 2020).

Another uncertain aspect that influences the quantified impacts of maintenance is the maintenance frequency, i.e. how often maintenance is conducted during the analysis period. Estimating the maintenance frequency is difficult because of the uncertainties involved in predicting the many factors that influence infrastructure performance, for example climate, material characteristics, and future traffic. The topic of maintenance frequency has gained some attention in the field of infrastructure LCA. Several studies have concluded that the maintenance stage is often calculated without accounting for realistic maintenance schedules (Santero et al. 2011a; AzariJafari et al. 2016; Hamdar et al. 2016; Inyim et al. 2016; Jiang and Wu 2019).

Yet another uncertain aspect of importance in infrastructure LCA is the change in external factors, such as the biosphere, that could influence future maintenance needs. Due to the commonly long analysis periods used in infrastructure LCA such changes are likely to occur during the analysis period. Future climate change is predicted to affect the infrastructure's structural performance, and thereby its maintenance frequency, due to, for instance, changes in temperature, precipitation, and frequency of extreme whether events (Arent et al. 2014).

Previous literature reviews have noted that limitations in the calculation of maintenance related impacts hinder the utility (Santero et al. 2011a) and implementation (Jiang and $\mathrm{Wu}, 2019$ ) of road LCAs, as well as the ability to determine which road surface material that has the lowest environmental impacts (Santero et al. 2011a; Inyim et al. 2016). However, these reviews do not describe the methodological approaches used in the reviewed LCAs or the reasons why a particular approach was chosen. Depending on the decisioncontext, for example a procurement or a policy decision, there are different requirements on a LCA (Butt et al. 2015). Hence, the appropriate approach to consider future maintenance in LCA will likely depend on the decision-context. As LCA is used more frequently in infrastructure policy and procurement, the choice of methodological approach becomes of increased importance.

This study aims to conduct a systematic literature review to map and describe approaches used in LCA of road and rail infrastructure. The study maps approaches used to (1) determine the length of the analysis period, (2) estimate the maintenance frequency, and (3) include the effects of future climate change on the service life and the maintenance frequency. The relevance of the approaches for decisionmaking is then covered from two perspectives: (1) based on characteristics of the construction solutions analysed and (2) based on characteristics of specific decision-contexts.

\section{Method}

The papers included in the literature review were found through a systematic process of searching electronic databases, applying inclusion criteria, and conducting backward and forward snowballing. The papers were analysed to find approaches used to (1) determine the length of the analysis 
period, (2) estimate the maintenance frequency, and (3) include the effects of future climate change on service life and maintenance frequency.

\subsection{Inclusion criteria}

Eight inclusion criteria were applied to the papers identified in the database search. Papers were included that:

1. Apply environmental LCA

2. Are about road or rail infrastructure

3. Account for future infrastructure maintenance

4. Are written in English

5. Are published in peer-reviewed scientific journals

6. Are published January 2016-July 2020

7. Perform a comparative LCA

8. Perform a project level LCA

The term maintenance can cover several activities, such as regular maintenance, repairs, and rehabilitations. In the review, LCAs that account for an activity that could be classified as maintenance (i.e. an activity conducted after construction but before end-of-life with the aim to maintain or restore the infrastructure's function) were included.

The review was limited to papers published January 2016-July 2020 covering a large body of publications. Although the limited search period risks excluding relevant publications, it can be assumed that important methodologies used in earlier research are also used in the publications included.

The review was also limited to comparative LCAs covering comparisons of construction materials, construction technologies, road locations, design alternatives, and maintenance strategies. The methodological issues considered in this study (analysis period, maintenance frequency, and climate change effects) are more important in comparative LCAs than in stand-alone LCAs. In comparative LCAs, the compared alternatives can have different characteristics and the approach used to calculate maintenance related impacts might therefore affect the outcome of the study.

Additionally, the review focused on studies at the project level; network level studies were not included. This delimitation was made since the review focuses on future maintenance of new construction projects.

\subsection{Databases and snowballing}

Three databases were used in the literature search: Scopus, Web of Science, and GreenFile. Scopus and Web of Science were chosen for their large coverage of literature within the fields of natural science and engineering. GreenFile was chosen because of its specific focus on topics related to environmental impacts.
The databases were searched on 31 March 2020. After duplicates had been removed and the inclusion criteria had been applied, backward snowballing (searching through the reference list of the selected papers) and forward snowballing (searching for papers referring to the selected papers) were used to find additional papers that fulfilled the inclusion criteria. Finally, the three databases were searched again on 20 July 2020 to find papers that had been published since the search in March.

\subsection{Search criteria and search string}

The first step of the literature review was a broad database search aiming to find papers that include LCA of road and rail infrastructure. The first search criterion was that the paper includes a LCA. The second search criterion was that the paper covers road or rail infrastructure. Since the term maintenance (and its synonyms) is not necessarily used in titles, abstracts, or keywords of infrastructure LCAs (even when included in the scope) it was not included in the search string. Exclusion search terms were not added. The same search string was used in all three databases. Based on the search criteria, the following search string was used to search within article titles, abstracts, and keywords:

("life cycle assessment" OR LCA OR"life cycle analys*") AND (road* OR rail* OR pavement* OR bridge* OR tunnel*).

\subsection{Paper selection}

The papers were selected through a stepwise procedure outlined in Fig. 1.

First, 3859 papers were identified in the initial database searches in March 2020. When duplicates, conference papers, books, and book chapters had been removed, the remaining papers were screened in multiple stages: first based on the title, then based on the abstracts, and finally based on the full text. The full texts of 14 papers were not found.

Second, the scope of the review was focused on comparative LCAs published January 2016-July 2020 and additional papers were removed. The remaining papers were screened to find comparative LCAs on a project level and to remove network level LCAs and stand-alone LCAs. The database search in July was made following the same procedure as the search in March.

Third, for the resulting list of papers, backward and forward snowballing were conducted until no more studies were found. During snowballing (both backwards and forwards), only papers published January 2016-July 2020 were screened (using the same procedure as for the database searches).

In the end, 92 papers were selected for the review. 
Fig. 1 Process for literature search

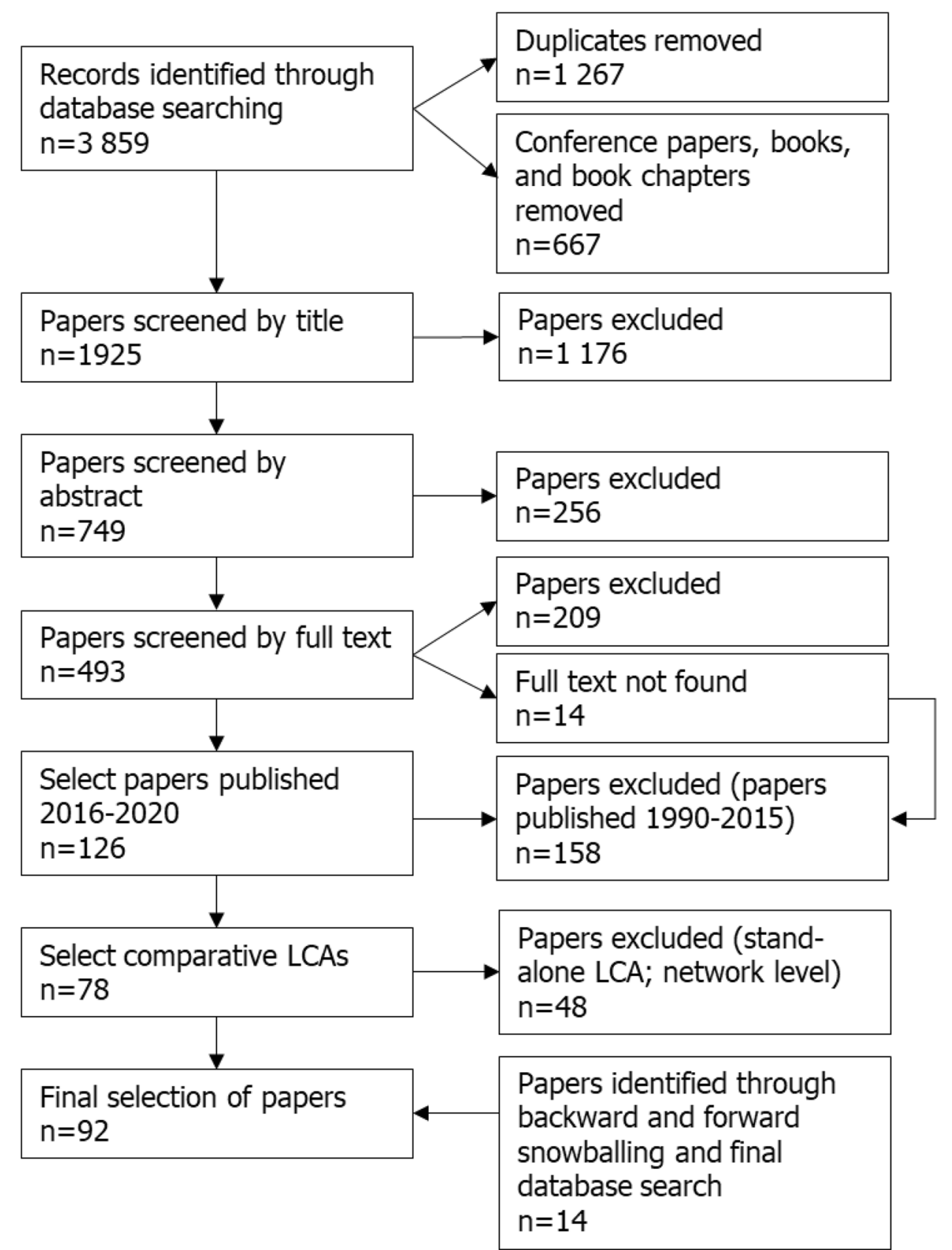

\subsection{Data collection process}

The analysis focused on finding the papers' arguments (including the references supporting these arguments) for determining analysis period, estimating maintenance frequency, and considering effects of future climate change. The arguments were categorised into different approaches (see Sect. 3) based on common characteristics identified by the authors of this review. If a paper supported an argument by referring to another study, the paper was categorised according to the approach used in the original reference.
Papers comparing innovative and conventional construction solutions are described in Sect. 3.5.2. In this review, innovative construction solutions are defined as solutions that are not yet used in practice, solutions that have been used for a short time, and solutions that have been available for some time but are not commonly used. Papers that described the construction solutions as innovative, emerging, new, or a contrast to conventional solutions were considered to include innovative solutions. 


\section{Results}

\subsection{Description of the studies included in the review}

Table 4 (in the Appendix) presents the scope of the reviewed papers, including the forms of infrastructure covered and the construction alternatives compared.

Out of the 92 papers included, 84 papers were about road infrastructure (whereof 1 was for pedestrian traffic) and 7 about rail infrastructure (Table 4 in the Appendix). One paper analysed a component that can be applied in both road and rail infrastructure.

Different types of road and rail infrastructure were covered in the reviewed literature (Table 4 in the Appendix). Most of the road LCAs were about surface roads (53 papers) and bridges (22 papers). Other forms of infrastructure were less common: tunnels ( 3 papers), roundabouts (1 paper), crash barriers (1 paper), anti-glare devices ( 1 paper), culverts (1 paper), and road drainage (1 paper). One paper included three forms of infrastructure: bridge, tunnel, and surface road. The rail infrastructure LCAs covered track beds ( 3 papers), bridges ( 2 papers), noise and vibration mitigation measures ( 1 paper), and sleepers (1 paper).

The papers compared a variety of construction materials, construction technologies, road locations, design alternatives, and maintenance strategies (Table 4 in the Appendix). Most of the papers compared different construction materials. For example, 38 of the road LCAs compared different types of road surface materials. Additionally, a common aim (in about $50 \%$ of the papers) was to compare a conventional construction solution with an innovative construction solution (Table 4 in the Appendix).

\subsection{Approaches used to determine the length of the analysis period}

The analysis period, which determines for how many years into the future the maintenance stage is accounted for, has a significant influence on the LCA results. The analysis period should not be confused with the infrastructure service life, which is the intended life length of the infrastructure. Although the analysis period can be equal to the service life, it does not have to be. A service life can be specified for the complete project (for example the service life of a bridge) and for each individual component of the infrastructure (for example the road surface on the bridge). The latter case is related to the maintenance frequency since infrastructure is designed for a specific service life, assuming regular maintenance when needed.

Based on the publications in this review, nine approaches to determine the analysis period were identified
Table 1 Approaches used to determine length of the analysis period and share of papers applying each approach based on how the papers were categorised in this review

\begin{tabular}{ll}
\hline Approach to determine analysis period & $\begin{array}{l}\text { Share of papers } \\
\text { applying the } \\
\text { approach }^{1}\end{array}$ \\
\hline Design service life & $30 \%$ \\
Estimated by experts & $2 \%$ \\
Predicted performance & $2 \%$ \\
Period of use & $2 \%$ \\
Service life of adjacent infrastructure & $1 \%$ \\
Fixed analysis period & $7 \%$ \\
Fixed number of maintenance cycles & $4 \%$ \\
Combination of approaches & $4 \%$ \\
No motivation & $54 \%$ \\
\hline
\end{tabular}

${ }^{1}$ The total does not equal $100 \%$ since some papers use multiple approaches

(Table 1). A large share of the papers (54\%) provided no motivation for choice of approach (either no argument was made, the references used could not be accessed, or the original reference did not support the arguments made). Some papers (4\%) used a combination of the approaches listed in Table 1 to find an analysis period fitting the scope of the study. The other seven approaches were divided into two main categories: (1) approaches based on the service life and (2) approaches based on a fixed analysis period or a fixed number of maintenance cycles.

\subsubsection{Service life}

In $37 \%$ of the papers, the analysis period was determined based on the infrastructure service life (Table 5 in the Appendix). However, the service life was defined in various ways. Often (in $30 \%$ of the papers), the service life was the same as the design service life, i.e. the intended life length of the infrastructure. The design service life was estimated using several different sources, including regional or European guidelines for infrastructure design, design information, and the desired service life for a specific construction project. In other cases $(2 \%)$, the service life was estimated by experts (such as manufacturers or others with knowledge about the construction sector) or based on predicted performance $(2 \%)$ by using modelling or laboratory tests. In a couple of papers $(2 \%)$, the service life explicitly represented the actual period of use, which may be significantly different from the design service life. In one case (1\%), the analysis period equalled the service life of adjacent infrastructure (sewer pipes) with the motivation that the road must be rebuilt when replacing the sewer pipes under the road. 


\subsubsection{Fixed analysis period or number of maintenance cycles}

In some papers (11\%), the analysis period had no direct connection to the service life of a specific construction project. In these papers (Table 5 in the Appendix), the analysis period sometimes represented fixed temporal boundaries (7\%), i.e. a fixed analysis period, that were specified in guidelines for assessment methods such as LCA (through Product Category Rules), life cycle cost analysis (LCCA), or cost-benefit analysis. In a few other papers (4\%), the analysis period was instead chosen to cover a fixed number of maintenance cycles for each alternative.

\subsection{Approaches used to estimate the maintenance frequency}

The maintenance frequency specifies how often maintenance is conducted during the analysis period and it could therefore have a significant influence on the results of a LCA.

The following approaches to estimate maintenance frequency were found in the reviewed papers: current practice $(37 \%)$, laboratory tests (4\%), modelling (37\%), and scenarios (8\%) (Table 2). Some papers used a combination of approaches; however, in this review, each approach is described individually. For $25 \%$ of the papers, it could not be determined how the maintenance frequency was estimated (either no motivation was provided, the references used could not be accessed, or the original reference did not support the arguments made).

\subsubsection{Current practice}

In $37 \%$ of the papers, the maintenance frequency was estimated based on current practice of infrastructure maintenance (Table 6 in the Appendix). Even though these papers shared a principally similar approach, "current practice" was determined in a variety of ways. The most common

Table 2 Approaches used to estimate maintenance frequency and share of papers applying each approach based on how papers were categorised in this review

\begin{tabular}{ll}
\hline Approach to estimate maintenance frequency & $\begin{array}{l}\text { Share of papers } \\
\text { applying the } \\
\text { approach }\end{array}$ \\
\hline Current practice & $37 \%$ \\
Laboratory tests & $4 \%$ \\
Modelling & $37 \%$ \\
Scenarios & $8 \%$ \\
Not possible to determine & $25 \%$ \\
\hline
\end{tabular}

${ }^{1}$ The total does not equal $100 \%$ since some papers use multiple approaches way (applied in more than half of the papers using a current practice approach) was a reference to a maintenance plan currently used by a transport agency, to construction guidelines, or to national standards and regulations. Current practice was also estimated by experts (such as manufacturers, construction companies, and designers) through for example interviews, surveys, statistics, and field observations.

\subsubsection{Laboratory tests}

In $4 \%$ of the papers, the maintenance frequency was estimated based on laboratory tests (Table 6 in the Appendix) in which a surface material was tested in a laboratory to determine its durability.

Two papers using laboratory tests conducted fatigue testing of asphalt mixtures. The tests were based on laboratory prepared specimens as well as cores from full-scale application in a trial section or in a testing facility. In another paper, the method used could not be traced from the original sources. In all three cases, material durability was evaluated relative to another material. In the fourth paper, no physical sample was analysed; rather, embedded sensors registering the material condition was applied to a road surface in a testing facility.

In the paper using full-scale application at a testing facility, the approach was motivated by the importance of determining a mixture's field performance and the limitations associated with current practice approaches and tests on laboratory prepared specimens: they cannot be used to predict actual maintenance demand and actual behaviour of asphalt mixtures (Saeedzadeh et al. 2018).

\subsubsection{Modelling}

Modelling was used in $37 \%$ of the studies to estimate the maintenance frequency (Table 6 in the Appendix). This approach is characterised by the use of models that predict the future infrastructure condition (and thereby when maintenance is needed) based on the infrastructure's present state and future scenarios related to parameters affecting maintenance needs. The reason for estimating maintenance frequency based on modelling was rarely stated explicitly. However, in one case, modelling was chosen due to limitations with laboratory tests: there is no correlation between laboratory results and material durability in practice (Rodríguez-Fernández et al. 2020).

In the reviewed papers, modelling was used for a variety of infrastructure types, including different types of road surface materials, concrete bridges, ballast layers, and crash barriers. Several types of models based on different underlying principles were used. In all bridge LCAs that applied modelling, diffusion of chloride ions in the concrete was modelled. Among the road LCAs, both empirical, 
mechanistic-empirical (ME), and probabilistic models were used. Additionally, the papers included several expressions of road surface performance, such as cracking, rutting, roughness, "pavement condition index", and "present serviceability index".

Three of the papers using modelling aimed to compare different performance measures or different performanceprediction models. They showed that choice of performance measure affect ranking of alternatives (Hamdar et al. 2020) and lead to different estimated service lives (Hong and Prozzi 2018). They also noted that, although different performance-prediction models lead to different absolute results, the relative difference between materials is the same regardless of the model used (Rodríguez-Fernández et al. 2020).

\subsubsection{Scenarios}

In $8 \%$ of the papers, scenarios were used instead of a fixed maintenance frequency (Table 6 in the Appendix). These papers assumed that the maintenance frequency depends on some factor and several values for this factor were compared. In the papers, the maintenance frequency was assumed to depend on various factors including the maintenance budget (3 papers), the traffic load (1 paper), the maintenance practice ( 1 paper), and the material performance ( 2 papers).

\subsection{Approaches used to include effects of future climate change}

The analysis period in an infrastructure LCA is often long. About $70 \%$ of the papers reviewed applied an analysis period of 30 years or more (Table 5 in the Appendix). Consequently, most infrastructure projects analysed are expected to be used in 2050 or thereafter. During this analysis period, climate change might significantly influence the service life and maintenance frequency of infrastructure.

The majority of the papers reviewed did not consider climate change effects in the LCA (Table 3). Most papers (96\%) did not mention the possible effect of climate change on the service life or the maintenance frequency. One paper $(1 \%)$ acknowledged that such changes might happen and that including them could affect the results of the study, but the effect on environmental impacts was not quantified (Batouli et al. 2017). In one paper (1\%), which included both a LCA and a LCCA, the effect of climate change on the maintenance frequency was considered in a sensitivity analysis for LCCA results (Cadenazzi et al. 2020).

In only two papers (2\%), effects of climate change were considered when determining maintenance frequency in a LCA. Tuler and Kaewunruen (2017) compared alternative noise and vibration mitigation measures in a control case and in adverse climates; however, what is considered an adverse climate was unspecified. Setsobhonkul et al.
Table 3 Approaches used to consider the effects of climate change and share of papers applying each approach based on how papers were categorised in this review

\begin{tabular}{ll}
\hline Approach to consider climate change effects & $\begin{array}{l}\text { Share of papers } \\
\text { applying the } \\
\text { approach }\end{array}$ \\
\hline Not mentioned & $96 \%$ \\
Quantified in sensitivity analysis for LCCA & $1 \%$ \\
Mentioned, but not quantified & $1 \%$ \\
Considered when determining & $2 \%$ \\
maintenance frequency in LCA & \\
\hline
\end{tabular}

(2017) compared designs of transition zones between bridge and embankment in a control case and in case of hot/cold temperatures and floods. Neither of the papers considered regional climate change effects in a specific country. Rather, they specified, based on previous studies, how the service life and the maintenance frequency depended on general climate parameters, such as an adverse climate (Tuler and Kaewunruen 2017) or a hot climate (Setsobhonkul et al. 2017).

\subsection{Use of approaches considering characteristics of the alternatives compared}

Certain aspects in comparative LCA require that approaches to determine analysis period, estimate maintenance frequency, and include climate change effects are chosen carefully. This section illustrates how approaches were applied in comparative LCAs characterised by one of the following: (1) the alternatives have different service lives or (2) at least one of the alternatives is an innovative construction solution. This illustration provides further insight into the application of the approaches.

\subsubsection{Comparing alternatives with different intended service lives}

About $25 \%$ of the papers compared alternatives that have different intended service lives (Table 5 in the Appendix). When the alternatives have different service lives, the choice of approach to determine the analysis period poses a certain challenge because the alternatives must be compared fairly even though one has a longer service life than the other. In the papers reviewed, different ways to handle this situation were found.

A common approach in the papers was to compare the alternatives over a joint analysis period. The length of this joint analysis period was determined in different ways. The service life of each alternative was estimated using one of the approaches from Table 1. A joint analysis period was then chosen to correspond to the longest service life (e.g. Chen 
et al. 2016; Noda et al. 2016; Huang et al. 2018; RodríguezAlloza et al. 2019; Cadenazzi et al. 2019, 2020; Landi et al. 2020), the shortest service life (Stripple et al. 2016; Cantisani et al. 2018), or a common denominator between the service lives (Liu et al. 2020). Others used an analysis period in which each alternative is rehabilitated at least once (Puccini et al. 2019) or that includes a complete life cycle of all alternatives (Batouli et al. 2017).

The papers applying a joint analysis period accounted for continuous replacement and maintenance of structures until the end of the analysis period. Papers that considered the end-of-life of alternatives also accounted for reconstruction of the alternative with the shortest service life (e.g. Noda et al. 2016; Stripple et al. 2016; Simões et al. 2017; Al-Ayish et al. 2018; Rodríguez-Alloza et al. 2019; Cadenazzi et al. 2019, 2020; Rempelos et al. 2020).

In a few other cases, no joint analysis period was determined. In these cases, various approaches listed in Table 1 were used to determine the service life of each alternative. One paper compared the alternatives using different service lives (Farina et al. 2017). In other papers (O'Born et al. 2016; Dolci et al. 2020), the results were annualised so that alternatives were compared over one year. Others used scenarios so that the alternatives were compared assuming different analysis periods (Krezo et al. 2016) or adjusted the functional unit so that the different service lives are reflected in the surface area constructed and maintained (Haslett et al. 2019).

\subsubsection{At least one of the alternatives is an innovative construction solution}

In about $50 \%$ of the reviewed papers, the aim was to compare the environmental impacts of conventional and innovative solutions (Table 4 in the Appendix). This situation poses specific challenges when determining maintenance frequency since the construction solution has not been used in practice and, consequently, only little information is available about its performance. Twelve of the papers analysing innovative construction solutions did not specify which approach was used to determine maintenance frequency. The other papers used one of the approaches identified in Sect. 3.3 to estimate the maintenance frequency of the innovative solutions.

A current practice approach was sometimes used (12 papers) for innovative construction solutions. In one paper, this choice was motivated by a lack of data for the innovative solution (Bizjak and Lenart 2018). In other cases (Bizjak et al. 2017; Santos et al. 2018a; Hasan et al. 2020), it was assumed that current practice was representative also for the innovative solution, for example because previous studies had shown that the performance of the innovative and conventional material was the same (Santos et al. 2018a; Hasan et al. 2020). In several cases (Bizjak et al. 2017; Umer et al. 2017; Bizjak and Lenart 2018; Santos et al. 2018a, 2019; Hasan et al. 2020), the uncertainty introduced by using a current practice approach was acknowledged. Either, it was suggested that a sensitivity analysis be made in additional research (Hasan et al. 2020) or a sensitivity analysis (Bizjak et al. 2017; Bizjak and Lenart 2018; Santos et al. 2018a, 2019) or uncertainty analysis (Umer et al. 2017) was included. Two papers used expert estimations (Peñaloza et al. 2018; Iwase et al. 2020). In this review, expert estimations were considered a current practice approach (in 3.3.1); however, experts could consider special characteristics of the innovative materials in their assessments. In other cases, current practice approaches were used when a conventional technology was applied in a non-traditional setting (Cantisani et al. 2018) and when a technology had been available for some time but was less commonly used than other technologies (Liu et al. 2020).

Modelling was used to determine the maintenance frequency of innovative solutions in several papers (17 papers). These papers covered a variety of infrastructure forms and models. Generally, the papers did not describe the representativeness of the models for the innovative materials. However, Simões et al. (2017) noted that material degradation curves based on real data could not be predicted due to lack of case studies investigating material conditions in different situations. Thus, to conduct the study they had to use a standard degradation curve. In other cases, a sensitivity analysis was conducted to evaluate the model's effect on the results (Chen et al. 2016; Bressi et al. 2018; Balieu et al. 2019).

In the majority of papers that used laboratory tests to determine maintenance frequency ( 3 papers) the aim was to assess the environmental impacts of an innovative solution. In all these papers (Lizasoain-Artega et al. 2019; Landi et al. 2020; Manosalvas-Paredes et al. 2020), a current practice approach was used for the conventional solution.

In some cases (5 papers), scenarios were used to compare innovative and conventional construction solutions and thereby consider uncertain aspects related to maintenance frequency, such as maintenance budget (Mauro and Guerrieri 2016; Guerrieri et al. 2020), choice of maintenance practice (Santos et al. 2017b), and material performance (Ma et al. 2019; Dolci et al. 2020).

\section{Discussion}

Assessment of future maintenance is a challenge in infrastructure LCA due to infrastructures' long lifetimes and dynamic performance. This study provides a basis for evaluating the relevance of approaches to calculate maintenance related impacts in different decision-contexts and critically 
discuss the method choice. Results can be used to suggest what approach to use in a LCA supporting a specific decision-context. The discussion focuses on the use of different approaches in transport infrastructure policy and procurement, two decision-contexts where the use of infrastructure LCA is rapidly expanding.

\subsection{Use of the approaches in policy and in procurement}

The approaches identified in the literature review have different characteristics. Considering that a LCA conducted in a specific decision-context may need to fulfil specific requirements, the approaches identified are more or less relevant in decision-making. Since the papers reviewed rarely expressed which decision the results were intended to support, they could not be used to determine the relevance of the approaches in specific decision-contexts. Therefore, this section first describes how characteristics of policy and procurement contexts are defined in this study and then discusses how the approaches identified in the reviewed papers match these characteristics.

In a policy context, the LCA aims to support decisions concerning multiple projects. The aim is to provide general suggestions and it is important that the relative importance of different aspects can be identified. For example, a LCA in a policy context could aim to suggest which technical solution or type of material should be generally preferred.

In a procurement context on the other hand, the LCA aims to support a decision in a specific construction project. The aim is to choose the best technical solution or material in a specific construction project. In that case, the quantitative difference between two alternatives becomes more important than in a policy context. To allow a fair comparison, the alternatives must be evaluated using the same methodological approach (Butt et al. 2015). Further, contractors' claims about environmental performance need to be transparent and comprehensible so that the procuring agency can follow-up the claims with a reasonable amount of effort. Standardised methods that can be required by the procuring agency may therefore be useful.

\subsubsection{Approaches based on current practice}

Approaches representing current practice were commonly used both to determine the analysis period (by using design guidelines, expert assessments, and assessment methods or by estimating the period of use) and to estimate the maintenance frequency.

In the reviewed papers, a current practice approach was applied for analysis periods of up to 100 years (including in papers comparing alternatives with different service lives). However, in both policy and procurement, using current practice to determine analysis period and maintenance frequency would be more representative over a relatively short time-frame when significant changes to the current situation are not expected. For long analysis periods, the development of technology and external factors is too uncertain to assume that current practice continues. For instance, the current practice approaches cannot include the effects of climate change on infrastructure. Therefore, it is suggested that LCA practitioners use current practice approaches primarily when the service life or the analysis period is relatively short. If a current practice approach is used over a long analysis period, due to for instance data availability, it is suggested that LCA practitioners apply sensitivity analysis, uncertainty analysis, or multiple scenarios to evaluate the uncertainty in the results.

A current practice approach was also applied for innovative solutions (in some cases when comparing alternatives with different service lives); however, the approach is likely more representative for conventional construction solutions (for which there are experience based evaluations, guidelines, or statistics) than for innovative solutions. If the innovative solution has not been used in practice and there is no data on its actual performance, it would be problematic to assume that current practice is a relevant approach to determine maintenance frequency or service life. Therefore, it is suggested that LCA practitioners use current practice approaches primarily for conventional construction solutions.

Regarding innovative solutions, a current practice approach may be of limited use in both policy and procurement contexts. Compared to a conventional alternative, an innovative solution could have higher production related impacts but, due to lower maintenance frequency and longer service life, lower impacts over its complete life cycle. In that case, a LCA that assumes that both alternatives have the same maintenance frequency would miss the benefits of the innovative material. Hence, if suggestions were based on LCAs that assume current practice, there would be little incentive to use and develop innovative materials with low environmental impacts.

In policy, LCA practitioners could avoid potential problems of using a current practice approach by applying sensitivity analysis, uncertainty analysis, or multiple scenarios to evaluate possible alternative outcomes (as was done in several papers in Sect. 3.5.2). Alternatively, a combination of approaches could be used. For example, a current practice approach could be applied for the conventional solution and scenarios or laboratory tests could be applied for the innovative solution (see for example papers reviewed in Sects. 3.3.2 and 3.3.4). In a procurement context, however, the same calculation method must be applied for all alternatives to compare the alternatives fairly. If a current practice approach is used in the LCA, the procuring agency 
could combine LCA results with technical requirements. For example, if an innovative asphalt mixture is expected to last longer than its competitor does, LCA results and technical performance (verified through results from a predefined physical test) could be the basis of selection.

\subsubsection{Approaches based on expert assessments}

By using expert assessments (through for example surveys or interviews) to determine analysis period and maintenance frequency LCA practitioners could receive estimates that consider developments related both to climate and to innovative solutions. However, evaluations may vary between expert groups; thus, it could be hard to achieve a robust basis for comparison using expert assessments. For example, in the survey used by Mazumder et al. (2018), the experts' assessments of the crack sealant treatments' durability varied significantly. If the LCA results are to be used in a procurement setting, expert opinions could be too subjective and other methods would be more suitable. In development of policy on the other hand, where it is here suggested that LCA practitioners assess various alternatives, a large variety of opinions could be considered and expert assessments fit well into the decision framework.

\subsubsection{Approaches based on modelling and laboratory tests}

Modelling and laboratory tests were commonly used to estimate maintenance frequency and in a few cases used to determine analysis period (also when alternatives have different service lives). For LCA practitioners, these approaches could have benefits in both policy and procurement contexts. Modelling has been requested for use in LCA to provide better estimate of maintenance related impacts (Santero et al. 2011a). Additionally, modelling and laboratory tests can consider climate specific aspects, although the approaches were not used for that purpose in the reviewed papers. For example, performance-prediction models that consider the current local climate (see for example Hamdar et al. (2020) and Xu et al. (2019)) may incorporate scenarios for a future climate. For instance, Valle et al. (2017) and Guest et al. (2020) have investigated how climate change can be included in road LCA and incorporated climate scenarios in ME models to determine maintenance frequency of road surfaces. Moreover, in a procurement setting, modelling and laboratory tests could provide a standardised way to provide evidence of a material's performance.

However, modelling and laboratory tests also have potential limitations that LCA practitioners should consider when selecting approach. Models that are based on longterm observations of infrastructure performance face the same challenges as the current practice approaches when it comes to innovative materials and future climate change (see Sect. 4.1.1). Therefore, in a procurement setting that involves innovative materials, the procuring agency must ensure that the models and tests provide a fair comparison of conventional and innovative materials. Additionally, performance-prediction models are not available for all materials and structures and there is a need for locally calibrated models for representative results. Hence, in many LCA, models representative of the specific construction solution may be unavailable and other approaches would be more suitable.

\subsubsection{Approaches based on scenarios}

Scenarios could be useful for LCA practitioners when performance is uncertain (as would be the case for many innovative solutions) and in the case where laboratory tests and performance-prediction models are inapplicable. Scenarios can be used to determine the analysis period (also when alternatives have different service lives), estimate the maintenance frequency (also for innovative solutions), and account for the effects of climate change.

In policy where the LCA aims to provide general recommendations, it is suggested that LCA practitioners compare multiple scenarios. Future scenarios regarding climate change should also be included. If results are consistent across multiple scenarios, the conclusions are more robust. Although it could be assumed that most papers reviewed are for policy purposes (since most conclude their papers by providing general suggestions), only few considered the uncertain performance by using scenarios.

In a procurement on the other hand, scenarios are more difficult to use. In a procurement setting, LCA practitioners should use previously developed consistent and generic scenarios. The use of such scenarios has also been suggested by Höjer et al. (2008) for general application in LCA. Additionally, the procuring agency could complement the LCA based requirements by policy based technical requirements on the construction.

\subsection{Contribution and suggestion for further studies}

\subsubsection{Using ME models to predict infrastructure performance}

Previous literature reviews have emphasised the lack of infrastructure performance in infrastructure LCA (Santero et al. 2011a; Inyim et al. 2016) and have suggested that research should be directed towards including material deterioration (Inyim et al. 2016) and integrating ME models (Santero et al. 2011a) in LCA. In this review, it was found that about $30 \%$ of the papers considered infrastructure performance through modelling and several of these papers used ME models. Hence, compared to findings in previous 
reviews, there appears to be a trend towards increased use of performance-prediction models in infrastructure LCA.

In contrast to previous reviews, this study reviewed the specific approaches used and discussed how they could be applied in policy and procurement. Although modelling has great potential to improve performance-predictions in both policy and procurement contexts, there are potential problems when comparing innovative and conventional construction solutions (Sect. 4.1.3) that hampers a fair comparison of alternatives in a procurement setting. Thus, before implementing modelling consistently in a standardised way, more research would be required.

\subsubsection{Including effects of climate change on infrastructure}

The use of scenarios to capture the effect of climate change on infrastructure was investigated, something that has not been covered in previous literature reviews. Even though significant changes may be expected to the climate only few studies included scenarios of climate change and their effect on maintenance frequency. However, other papers, not part of this review, have included climate change effects in road surface LCA, comparing environmental impacts of road surfaces under different climate change scenarios (temperature and precipitation) in the USA (Valle et al. 2017) and Canada (Guest et al. 2020).

Although LCA practitioners are here suggested to consider the effects of climate change on maintenance practices, including climate change in a LCA may be challenging. For example, a multitude of climate change effects influences the infrastructure in different ways (Qiao et al. 2020). These effects are connected to significant uncertainties related to regional effects and correlations between climate change and the quantitative effect on maintenance frequency and service life (ibid.).

More research on developing systematic approaches to integrate future climate change in LCA for policy and procurement is therefore important. For example, more research is needed to understand the effect of climate change on infrastructure service life in different regions. Additionally, more research has been suggested to consider the consequences of combined effects (Setsobhonkul et al. 2017), extreme weather events (Setsobhonkul et al. 2017; Guest et al. 2020) and the effect of climate change on vehicles and their influence on infrastructure performance (Valle et al. 2017). Further, it has been suggested to use more climate models and apply developed methods in additional case studies (Guest et al. 2020).

\subsubsection{Accounting for future scenarios in general}

LCA practitioners are here suggested to use scenarios for the evaluation of results under a range of possible outcomes.
Scenarios can be used both to consider climate change and other aspects related to maintenance frequency and analysis period, such as traffic load and maintenance budget (see Sects. 3.3.4 and 4.1.4). To incorporate scenarios in LCA, the LCA practitioner could draw knowledge from the field of futures studies and papers that have suggested ways to incorporate future scenarios in LCA in general.

Höjer et al. (2008) describe how scenarios could be generally integrated in LCAs with examples from predictive scenarios ("what will happen?"), explorative scenarios ("what can happen?"), and normative scenarios ("how can a specific target be reached?"). Höjer et al. (2008) suggest that in LCA of long-lived products, for long-term decisions, and when changes in trends are expected-all characteristics of infrastructure LCA - explorative scenarios are more relevant than predictive scenarios. Additionally, explorative scenarios are useful when predictive scenarios are considered too uncertain (which in turn depends on the aim of the study and the researchers' worldviews and perceptions) (Höjer et al. 2008), which could be the case under climate change.

In the reviewed papers that used scenarios to determine analysis period, estimate maintenance frequency, or include climate change effects, the most common scenario used was a what-if scenario (defined by Höjer et al. (2008) as a type of predictive scenario that answers the question "what will happen, on the condition of some specified event?"). Although these papers analysed results under various scenarios for external factors such as budget, traffic load, and temperature, none of the papers analysed the possible development of the external factors. Such an analysis would be, according to Höjer et al. (2008), a type of explorative scenario answering the question "what can happen to the development of external factors?". Considering the uncertainties involved in the maintenance phase, including more explorative scenarios to assess a wide range of potential outcomes could be beneficial for LCA practitioners in the interpretation of results.

\subsubsection{Reviewing additional literature}

The literature search in this study was limited to comparative LCAs published in peer-reviewed scientific journals. Although this scope is considered to fairly well cover available approaches, a natural extension for future research is reviews including LCA models, certification systems, reports, standards, and guidelines. Such sources could include approaches that are not yet published in peerreviewed journals but that could be highly relevant for understanding the practical implementation of LCA in policy and planning. Additionally, stand-alone LCAs and method development papers could be studied for other approaches and perspectives. Further reviews of each approach and decisioncontext could provide additional insights into the practical usability of the approaches identified in this review. 


\section{Conclusions}

LCA is becoming used more frequently in infrastructure policy and planning. The practical relevance of methodological approaches must therefore be critically evaluated considering that a LCA may need to fulfil specific requirements placed in a decision-context. This study has provided, through a review of 92 papers, an overview of approaches to include future maintenance in comparative road and rail infrastructure LCA. Specifically, the study has reviewed approaches used to determine analysis period, estimate maintenance frequency, and include effects of climate change. These three aspects could significantly influence the results of a LCA. The relevance of the approaches identified was addressed in different comparative situations and in policy and procurement contexts.

In the reviewed literature, the analysis period was based on the infrastructure service life or guidelines for assessment methods such as LCA or LCCA. In more than half of the papers, the choice of analysis period was not described. Papers comparing alternatives that have different service lives commonly applied a joint analysis period for all alternatives. Maintenance frequency was estimated based on current practice, laboratory tests, modelling, and scenarios, both in LCA of innovative and conventional construction solutions. In about one quarter of the papers, it was not possible to determine how the maintenance frequency had been estimated. Only two papers quantified the effects of climate change on maintenance frequency and considered its influence on environmental impacts of the maintenance stage.

Based on the papers reviewed and the approaches identified in this study, suggestions for how LCA practitioners could use the approaches are provided. In both policy and procurement, LCA practitioners are suggested to use current practice approaches primarily in LCAs of conventional materials and over relatively short analysis periods. Expert assessments, a special case of current practice approaches, could be considered too subjective for use in procurement, but could be used in a policy context to account for multiple outcomes. Through using modelling and laboratory tests, LCA practitioners could improve the estimation of maintenance frequency and service life in LCA for both policy and procurement purposes. However, the approaches may not necessarily provide a fair comparison of innovative and conventional construction solutions. In a policy context, LCA practitioners are suggested to apply multiple scenarios, including scenarios for climate change. In a procurement context, LCA practitioners are suggested to use consistent and generic scenarios that have been previously developed.

The LCA community is suggested to research the integration of other approaches than current practice in infrastructure LCA for more representative results related to innovative solutions and long analysis periods. Some examples based on this review include integration of explorative scenarios, climate change effects, and the practical application of models and laboratory tests in procurement. To further facilitate the practical implementation of LCA, literature not reviewed here, including stand-alone LCAs, literature on specific approaches and decisioncontexts, reports, certification systems, standards, and guidelines, could be reviewed for additional approaches and perspectives.

\section{Appendix}


Table 4 Characteristics of the studies included in the review: type of infrastructure and type of comparison made

\begin{tabular}{|c|c|c|c|c|}
\hline Road or rail & Specific type of infrastructure & Comparison made & $\begin{array}{l}\text { Compare innovative and } \\
\text { conventional construction } \\
\text { solutions }\end{array}$ & Reference \\
\hline Road & Anti-glare device & $\begin{array}{l}\text { Construction material (plastic } \\
\text { or steel) }\end{array}$ & No & Cherubini et al. (2019) \\
\hline Road & Bridge & Concrete mixes & No & Al-Ayish et al. (2018) \\
\hline Road & Bridge & Construction technologies & Yes & Bizjak and Lenart (2018) \\
\hline Road & Bridge & Construction technologies & Yes & Cadenazzi et al. (2019) \\
\hline Road & Bridge & $\begin{array}{l}\text { Construction materials, rein- } \\
\text { forcement }\end{array}$ & Yes & Cadenazzi et al. (2020) \\
\hline Road & Bridge & $\begin{array}{l}\text { Construction alternatives } \\
\text { (bridge designs) }\end{array}$ & No & Du et al. (2018) \\
\hline Road & Bridge & Optimal maintenance actions & No & García-Segura et al. (2017) \\
\hline Road & Bridge & $\begin{array}{l}\text { Different types of reinforced } \\
\text { concrete }\end{array}$ & Yes & Hajiesmaeili et al. (2019) \\
\hline Road & Bridge & Two types of bridge slabs & Yes & Iwase et al. (2020) \\
\hline Road & Bridge & $\begin{array}{l}\text { Three alternative bridge } \\
\text { designs }\end{array}$ & Yes & Lemma et al. (2020) \\
\hline Road & Bridge & Fifteen prevention strategies & Yes & Navarro et al. (2018) \\
\hline Road & Bridge & $\begin{array}{l}\text { Eighteen design alternatives } \\
\text { for a bridge }\end{array}$ & No & Navarro et al. (2019a) \\
\hline Road & Bridge & $\begin{array}{l}\text { Sixteen design alternatives } \\
\text { for a bridge }\end{array}$ & Yes & Navarro et al. (2019b) \\
\hline Road & Bridge & $\begin{array}{l}\text { Bridge designs: concrete vs } \\
\text { wood }\end{array}$ & Yes & O'Born (2018) \\
\hline Road & Bridge & $\begin{array}{l}\text { Adhesively bonded carbon } \\
\text { fibre reinforced polymer vs } \\
\text { steel plates }\end{array}$ & Yes & Orcesi et al. (2019) \\
\hline Road & Bridge & $\begin{array}{l}\text { Two optimal post-tensioned } \\
\text { concrete box-girder bridges }\end{array}$ & No & Penadés-Plà et al. (2017) \\
\hline Road & Bridge & $\begin{array}{l}\text { Bridge designs: concrete vs } \\
\text { wood }\end{array}$ & Yes & Peñaloza et al. (2018) \\
\hline Road & Bridge & $\begin{array}{l}\text { Two bridges (existing bridge } \\
\text { deck vs timber-concrete } \\
\text { composite) }\end{array}$ & Yes & Rodrigues et al. (2017) \\
\hline Road & Bridge & $\begin{array}{l}\text { Ultra-high performance } \\
\text { concrete vs conventional } \\
\text { concrete }\end{array}$ & Yes & Sameer et al. (2019) \\
\hline Road & Bridge & Eight different retrofit options & No & Tapia and Padgett (2016) \\
\hline Road & Bridge & Maintenance strategies & No & Xie et al. (2018) \\
\hline Road & Culvert & $\begin{array}{l}\text { Construction materials (dif- } \\
\text { ferent types of concrete and } \\
\text { reinforcing) }\end{array}$ & Yes & Redaelli et al. (2019) \\
\hline Road & Drainage & Construction alternatives & No & Byrne et al. (2017) \\
\hline Road & Crash barriers & $\begin{array}{l}\text { Four types of crash barriers: } \\
\text { two types of wood and two } \\
\text { types of steel }\end{array}$ & No & Noda et al. (2016) \\
\hline Road & Surface road & Road surface materials & No & AzariJafari et al. (2018) \\
\hline Road & Surface road & $\begin{array}{l}\text { Different types of electrified } \\
\text { roads }\end{array}$ & Yes & Balieu et al. (2019) \\
\hline Road & Surface road & $\begin{array}{l}\text { Different road surface materi- } \\
\text { als }\end{array}$ & No & Batouli et al. (2017) \\
\hline Road & Surface road & Road surface materials & No & Boonpoke et al. (2018) \\
\hline Road & Surface road & $\begin{array}{l}\text { Aggregate sources and } \\
\text { asphalt mixes }\end{array}$ & No & Butt and Birgisson (2016) \\
\hline
\end{tabular}


Table 4 (continued)

\begin{tabular}{|c|c|c|c|c|}
\hline Road or rail & Specific type of infrastructure & Comparison made & $\begin{array}{l}\text { Compare innovative and } \\
\text { conventional construction } \\
\text { solutions }\end{array}$ & Reference \\
\hline Road & Surface road & $\begin{array}{l}\text { Construction materials (road } \\
\text { surface, soil stabilisation); } \\
\text { maintenance strategies }\end{array}$ & No & Celauro et al. (2017) \\
\hline Road & Surface road & Road surface materials & Yes & Chen et al. (2016) \\
\hline Road & Surface road & Maintenance strategies & No & Choi (2019) \\
\hline Road & Surface road & $\begin{array}{l}\text { Construction materials (road } \\
\text { surface) }\end{array}$ & No & Choi et al. (2016) \\
\hline Road & Surface road & $\begin{array}{l}\text { Construction alternatives } \\
\text { (road base thickness) }\end{array}$ & No & Chong and Wang (2017) \\
\hline Road & Surface road & $\begin{array}{l}\text { Construction alternatives } \\
\text { (road base thickness) }\end{array}$ & No & Chong et al. (2018) \\
\hline Road & Surface road & $\begin{array}{l}\text { Construction materials (road } \\
\text { surface) }\end{array}$ & Yes & Cong et al. (2020) \\
\hline Road & Surface road & $\begin{array}{l}\text { Standard paving materials vs } \\
\text { bituminous mixtures con- } \\
\text { taining recycled materials }\end{array}$ & Yes & Farina et al. (2017) \\
\hline Road & Surface road & $\begin{array}{l}\text { HMA }^{1} \text { concrete, jointed plain } \\
\text { Portland cement concrete }\end{array}$ & No & Gregory et al. (2016) \\
\hline Road & Surface road & $\begin{array}{l}\text { Smart vs conventional } \\
\text { motorways }\end{array}$ & Yes & Guerrieri et al. (2020) \\
\hline Road & Surface road & $\begin{array}{l}\text { Different road paving tech- } \\
\text { nologies }\end{array}$ & No & Gulotta et al. (2018) \\
\hline Road & Surface road & $\begin{array}{l}\text { Different road paving tech- } \\
\text { nologies }\end{array}$ & Yes & Gulotta et al. (2019) \\
\hline Road & Surface road & $\begin{array}{l}\text { Eight asphalt mixes using } \\
\text { different binder grades and } \\
\mathrm{WMA}^{2} \text { additives }\end{array}$ & No & Hamdar et al. (2020) \\
\hline Road & Surface road & $\begin{array}{l}\text { Different types of aggregates } \\
\text { and road surface materials }\end{array}$ & Yes & Hasan et al. (2020) \\
\hline Road & Surface road & Maintenance strategies & No & Haslett et al. (2019) \\
\hline Road & Surface road & $\begin{array}{l}\text { Forty-two types of asphalt } \\
\text { concrete and plain cement } \\
\text { concrete }\end{array}$ & No & Heidari et al. (2020) \\
\hline Road & Surface road & $\begin{array}{l}\text { Reference mastic asphalt vs } \\
\text { temperature-reduced mastic } \\
\text { asphalt }\end{array}$ & Yes & Hofko et al. (2017) \\
\hline Road & Surface road & $\begin{array}{l}\text { RAP }^{3} \text { and virgin mixes with } \\
\text { different overlay thick- } \\
\text { nesses }\end{array}$ & No & Hong and Prozzi (2018) \\
\hline Road & Surface road & $\begin{array}{l}\text { Road surface material: } \\
\text { asphalt vs concrete }\end{array}$ & No & Huang et al. (2018) \\
\hline Road & Surface road & $\begin{array}{l}\text { Maintenance options: two } \\
\text { types of overlay }\end{array}$ & Yes & Krishna and Kumar (2020) \\
\hline Road & Surface road & Three types of HMA & Yes & Landi et al. (2020) \\
\hline Road & Surface road & $\begin{array}{l}\text { Permeable road surface vs } \\
\text { traditional road surface }\end{array}$ & Yes & Liu et al. (2020) \\
\hline Road & Surface road & $\begin{array}{l}\text { Induction healed asphalt mix } \\
\text { vs traditional asphalt mix }\end{array}$ & Yes & Lizasoain-Arteaga et al. (2019) \\
\hline Road & Surface road & $\begin{array}{l}\text { Three types of road surface } \\
\text { materials }\end{array}$ & Yes & Lu et al. (2019) \\
\hline Road & Surface road & WMA and HMA & Yes & Ma et al. (2019) \\
\hline Road & Surface road & $\begin{array}{l}\text { Maintenance plans: pre-set or } \\
\text { determined by embedded } \\
\text { sensors }\end{array}$ & Yes & $\begin{array}{l}\text { Manosalvas-Paredes et al. } \\
(2020)\end{array}$ \\
\hline
\end{tabular}


Table 4 (continued)

\begin{tabular}{|c|c|c|c|c|}
\hline Road or rail & Specific type of infrastructure & Comparison made & $\begin{array}{l}\text { Compare innovative and } \\
\text { conventional construction } \\
\text { solutions }\end{array}$ & Reference \\
\hline Road & Surface road & Road construction projects & No & Marzouk et al. (2017) \\
\hline Road & Surface road & $\begin{array}{l}\text { Maintenance strategies: crack } \\
\text { sealing or filling }\end{array}$ & No & Mazumder et al. (2018) \\
\hline Road & Surface road & $\begin{array}{l}\text { HMA and WMA with dif- } \\
\text { ferent types of recycled } \\
\text { materials }\end{array}$ & Yes & Praticò et al. (2020) \\
\hline Road & Surface road & $\begin{array}{l}\text { HMA and two types of } \\
\text { WMA }\end{array}$ & Yes & Puccini et al. (2019) \\
\hline Road & Surface road & $\begin{array}{l}\text { Self-healing road vs conven- } \\
\text { tional road }\end{array}$ & Yes & Rodríguez-Alloza et al. (2019) \\
\hline Road & Surface road & $\begin{array}{l}\text { Three technologies to } \\
\text { produce porous asphalt } \\
\text { mixtures }\end{array}$ & Yes & $\begin{array}{l}\text { Rodríguez-Fernández et al. } \\
\text { (2020) }\end{array}$ \\
\hline Road & Surface road & $\begin{array}{l}\text { Three recycled asphalt } \\
\text { mixtures compared with a } \\
\text { control virgin mixture }\end{array}$ & No & Saeedzadeh et al. (2018) \\
\hline Road & Surface road & Maintenance strategies & Yes & Santos et al. (2017a) \\
\hline Road & Surface road & $\begin{array}{l}\text { WMA and HMA technolo- } \\
\text { gies with and without RAP }\end{array}$ & Yes & Santos et al. (2018a) \\
\hline Road & Surface road & Maintenance strategies & Yes & Santos et al. (2018b) \\
\hline Road & Surface road & $\begin{array}{l}\text { Different types of HMA and } \\
\text { WMA }\end{array}$ & Yes & Santos et al. (2019) \\
\hline Road & Surface road & Maintenance strategies & No & Santos et al. (2020) \\
\hline Road & Surface road & $\begin{array}{l}\text { HMA and WMA with } \\
\text { different RAP contents, } \\
\text { two types of preventive } \\
\text { maintenance }\end{array}$ & Yes & Santos et al. (2017b) \\
\hline Road & Surface road & $\begin{array}{l}\text { HMA with and without } \\
\text { hydrated lime }\end{array}$ & No & Schlegel et al. (2016) \\
\hline Road & Surface road & Three maintenance strategies & Yes & Simões et al. (2017) \\
\hline Road & Surface road & $\begin{array}{l}\text { Various surface layers, base } \\
\text { layers, subbase layers, } \\
\text { sewer systems, bicycle } \\
\text { paths, footpaths }\end{array}$ & No & Trigaux et al. (2017) \\
\hline Road & Surface road & $\begin{array}{l}\text { Road surface alternatives } \\
\text { (flexible, concrete, geosyn- } \\
\text { thetics) }\end{array}$ & Yes & Umer et al. (2017) \\
\hline Road & Bridge & $\begin{array}{l}\text { Structural materials for } \\
\text { bridge girders: steel or pre- } \\
\text { stressed reinforced concrete }\end{array}$ & No & Wang et al. (2020) \\
\hline Road & Surface road & $\begin{array}{l}\text { Bitumen vs three types of } \\
\text { polystyrene waste to substi- } \\
\text { tute bitumen in asphalt }\end{array}$ & Yes & Vila-Cortavitarte et al. (2018) \\
\hline Road & Surface road & $\begin{array}{l}\text { Eighteen road surface designs } \\
\text { (flexible and rigid) in nine } \\
\text { different contexts }\end{array}$ & No & Xu et al. (2019) \\
\hline Road & Surface road & $\begin{array}{l}\text { Spall repair methods: conven- } \\
\text { tional vs 3D-printing }\end{array}$ & Yes & Yeon et al. (2020) \\
\hline Road & Surface road & $\begin{array}{l}\text { Three road surface alterna- } \\
\text { tives (HMA, WMA, and } \\
\text { RAP) }\end{array}$ & No & Zheng et al. (2020) \\
\hline Road & Surface road & $\begin{array}{l}\text { Three preservation treatments } \\
\text { vs "do nothing" alternative }\end{array}$ & No & Zulu et al. (2020) \\
\hline
\end{tabular}


Table 4 (continued)

\begin{tabular}{|c|c|c|c|c|}
\hline Road or rail & Specific type of infrastructure & Comparison made & $\begin{array}{l}\text { Compare innovative and } \\
\text { conventional construction } \\
\text { solutions }\end{array}$ & Reference \\
\hline Road & Roundabout & $\begin{array}{l}\text { Roundabout designs: conven- } \\
\text { tional double-lane, turbo, } \\
\text { and flower }\end{array}$ & Yes & Mauro and Guerrieri (2016) \\
\hline Road & Tunnel & $\begin{array}{l}\text { Design alternatives for a } \\
\text { tunnel }\end{array}$ & No & Audi et al. (2020) \\
\hline Road & Tunnel & $\begin{array}{l}\text { Construction materials (road } \\
\text { surface), lighting systems }\end{array}$ & Yes & Cantisani et al. (2018) \\
\hline Road & Tunnel & $\begin{array}{l}\text { Road surface: asphalt vs } \\
\text { concrete }\end{array}$ & No & Guo et al. (2019) \\
\hline Road & Tunnel, bridge, surface road & Road location alternatives & No & O'Born et al. (2016) \\
\hline Road, pedestrian & Bridge & $\begin{array}{l}\text { The one thousand most sus- } \\
\text { tainable bridge designs }\end{array}$ & No & Penadés-Plà et al. (2020) \\
\hline Road and rail & Tunnel & $\begin{array}{l}\text { New drainage system vs con- } \\
\text { ventional drainage system }\end{array}$ & Yes & Stripple et al. (2016) \\
\hline Rail & Bridge & Construction technologies & Yes & Bizjak et al. (2017) \\
\hline Rail & Bridge & $\begin{array}{l}\text { Eight techniques for railway } \\
\text { bridge transition mitigation }\end{array}$ & No & Setsobhonkul et al. (2017) \\
\hline Rail & $\begin{array}{l}\text { Noise and vibration mitiga- } \\
\text { tion measures }\end{array}$ & $\begin{array}{l}\text { Four noise and vibration } \\
\text { mitigation measures }\end{array}$ & Yes & Tuler and Kaewunruen (2017) \\
\hline Rail & Sleeper & $\begin{array}{l}\text { Four types of sleepers: mono- } \\
\text { block concrete, hardwood, } \\
\text { softwood, steel }\end{array}$ & No & Rempelos et al. (2020) \\
\hline Rail & Track bed & Construction technologies & Yes & Bressi et al. (2018) \\
\hline Rail & Track bed & $\begin{array}{l}\text { Construction alternatives } \\
\text { (sleepers) }\end{array}$ & Yes & Dolci et al. (2020) \\
\hline Rail & Track bed & Three track systems & Yes & Krezo et al. (2016) \\
\hline
\end{tabular}

$H M A$ hot mix asphalt, WMA warm mix asphalt, $R A P$ recycled asphalt pavement 
Table 5 Approach used to determine the length of the analysis period in each paper, reference used to motivate choice of analysis period, whether the paper compared alternatives with different service lives, and the length of the resulting analysis period

\begin{tabular}{|c|c|c|c|c|}
\hline $\begin{array}{l}\text { Approach to determine } \\
\text { length of analysis period }\end{array}$ & Reference to analysis period & $\begin{array}{l}\text { Compare alternatives } \\
\text { with different service } \\
\text { lives }\end{array}$ & Analysis period (years) & Reference \\
\hline Combination of approaches & $\begin{array}{l}\text { Reasoning based on construc- } \\
\text { tion practice and assessment } \\
\text { guidelines }\end{array}$ & Yes & 50 & Batouli et al. (2017) \\
\hline Combination of approaches & $\begin{array}{l}\text { Reasoning based on previous } \\
\text { studies }\end{array}$ & Yes & 100 & Cadenazzi et al. (2020) \\
\hline Combination of approaches & $\begin{array}{l}\text { US Federal Highway Admin- } \\
\text { istration's LCCA policy; } \\
\text { common analysis period } \\
\text { used in LCA }\end{array}$ & No & 40 & Choi (2019) \\
\hline Combination of approaches & $\begin{array}{l}\text { Local practice and US Federal } \\
\text { Highway Administration's } \\
\text { recommendations }\end{array}$ & No & 40 & Chong et al. (2018) \\
\hline Combination of approaches & $\begin{array}{l}\text { Match best practices for both } \\
\text { the LCCA and the LCA }\end{array}$ & No & 40 & Umer et al. (2017) \\
\hline Combination of approaches & $\begin{array}{l}\text { Typically anticipated service } \\
\text { duration }\end{array}$ & No & 30 & Yeon et al. (2020) \\
\hline Design service life & Construction guidelines & No & 25 & Butt and Birgisson (2016) \\
\hline Design service life & $\begin{array}{l}\text { Emerging and current state of } \\
\text { practice }\end{array}$ & Yes & 100 & Cadenazzi et al. (2019) \\
\hline Design service life & $\begin{array}{l}\text { Conventional service life of } \\
\text { flexible pavements' road } \\
\text { surfaces }\end{array}$ & Yes & 20 & Cantisani et al. (2018) \\
\hline Design service life & $\begin{array}{l}\text { Movement towards longer } \\
\text { service life }\end{array}$ & No & 50 & Choi et al. (2016) \\
\hline Design service life & $\begin{array}{l}\text { Typical design life of Chinese } \\
\text { motorway tunnels }\end{array}$ & No & 100 & Guo et al. (2019) \\
\hline Design service life & $\begin{array}{l}\text { Local government agency } \\
\text { guidelines }\end{array}$ & No & 30 & Hasan et al. (2020) \\
\hline Design service life & $\begin{array}{l}\text { Design service life according } \\
\text { to Indian standards }\end{array}$ & No & 20 & Krishna and Kumar (2020) \\
\hline Design service life & European design standards & No & 100 & Lemma et al. (2020) \\
\hline Design service life & $\begin{array}{l}\text { Design life according to Chi- } \\
\text { nese specifications }\end{array}$ & Yes & 36 & Liu et al. (2020) \\
\hline Design service life & $\begin{array}{l}\text { Required service life accord- } \\
\text { ing to European Committee } \\
\text { for Standardization }\end{array}$ & No & 100 & Navarro et al. (2018) \\
\hline Design service life & $\begin{array}{l}\text { Required by the Spanish Min- } \\
\text { istry of Public Works }\end{array}$ & No & 100 & Navarro et al. (2019a) \\
\hline Design service life & Design life of the bridge & No & 100 & Navarro et al. (2019b) \\
\hline Design service life & $\begin{array}{l}\text { Initial design service life of a } \\
\text { specific bridge }\end{array}$ & No & 100 & Orcesi et al. (2019) \\
\hline Design service life & $\begin{array}{l}\text { Design service life of the case } \\
\text { study bridge }\end{array}$ & No & 150 & Penadés-Plà et al. (2017) \\
\hline Design service life & $\begin{array}{l}\text { Design life of the bridge in the } \\
\text { case study }\end{array}$ & No & 80 & Peñaloza et al. (2018) \\
\hline Design service life & European design guidelines & No & 50 & Rodrigues et al. (2017) \\
\hline Design service life & Design service life of a bridge & No & 75 & Wang et al. (2020) \\
\hline Design service life & Design service life & No & 100 & Xie et al. (2018) \\
\hline $\begin{array}{l}\text { Design service life, predicted } \\
\text { performance }\end{array}$ & $\begin{array}{l}\text { Compare three methods to } \\
\text { determine service life }\end{array}$ & Yes & 100 & Al-Ayish et al. (2018) \\
\hline Estimated by experts & Estimations by manufacturer & No & 10 & Cherubini et al. (2019) \\
\hline
\end{tabular}


Table 5 (continued)

\begin{tabular}{|c|c|c|c|c|}
\hline $\begin{array}{l}\text { Approach to determine } \\
\text { length of analysis period }\end{array}$ & Reference to analysis period & $\begin{array}{l}\text { Compare alternatives } \\
\text { with different service } \\
\text { lives }\end{array}$ & Analysis period (years) & Reference \\
\hline $\begin{array}{l}\text { Estimated by experts, } \\
\text { predicted performance }\end{array}$ & $\begin{array}{l}\text { Expert estimates, laboratory } \\
\text { tests }\end{array}$ & Yes & 30 & Landi et al. (2020) \\
\hline Fixed analysis period & Product Category Rules & No & 60 & Bizjak et al. (2017) \\
\hline Fixed analysis period & $\begin{array}{l}\text { European Commission } \\
\text { guidelines for cost-benefit } \\
\text { analysis }\end{array}$ & No & 30 & Celauro et al. (2017) \\
\hline Fixed analysis period & $\begin{array}{l}\text { European Commission } \\
\text { guidelines for cost-benefit } \\
\text { analysis }\end{array}$ & No & 30 & Guerrieri et al. (2020) \\
\hline Fixed analysis period & $\begin{array}{l}\text { US Federal Highway Admin- } \\
\text { istration's guidelines for } \\
\text { LCCA of road surfaces }\end{array}$ & No & 35 & Heidari et al. (2020) \\
\hline Fixed analysis period & $\begin{array}{l}\text { European Commission } \\
\text { guidelines for cost-benefit } \\
\text { analysis }\end{array}$ & No & 30 & Mauro and Guerrieri (2016) \\
\hline Fixed analysis period & $\begin{array}{l}\text { WebTAG recommendations } \\
\text { for cost-benefit analysis }\end{array}$ & Yes & 60 & Rempelos et al. (2020) \\
\hline Fixed analysis period & $\begin{array}{l}\text { Longer than in the LCCA } \\
\text { guideline }\end{array}$ & Yes & 40 & Simões et al. (2017) \\
\hline $\begin{array}{l}\text { Fixed number of } \\
\text { maintenance cycles }\end{array}$ & $\begin{array}{l}\text { LCCA manual from California } \\
\text { Department of Transporta- } \\
\text { tion }\end{array}$ & Yes & $92-135$ & Haslett et al. (2019) \\
\hline $\begin{array}{l}\text { Fixed number of } \\
\text { maintenance cycles }\end{array}$ & ISO standard for acoustics & Yes & 72 & Puccini et al. (2019) \\
\hline $\begin{array}{l}\text { Fixed number of maintenance } \\
\text { cycles, no motivation }\end{array}$ & $\begin{array}{l}\text { For some track types: specified } \\
\text { number of renewals and } \\
\text { renewal frequency }\end{array}$ & Yes & $100-120$ & Krezo et al. (2016) \\
\hline No motivation & $\begin{array}{l}\text { Generally considered for civil } \\
\text { engineering structures }\end{array}$ & No & 100 & Audi et al. (2020) \\
\hline No motivation & Not specified & No & 50 & AzariJafari et al. (2018) \\
\hline No motivation & Not specified & No & 20 & Balieu et al. (2019) \\
\hline No motivation & $\begin{array}{l}\text { Most common lifetime of new } \\
\text { bridges }\end{array}$ & No & 100 & Bizjak and Lenart (2018) \\
\hline No motivation & Not specified & No & Not specified & Boonpoke et al. (2018) \\
\hline No motivation & Not specified & No & 60 & Bressi et al. (2018) \\
\hline No motivation & Not specified & No & 60 & Byrne et al. (2017) \\
\hline No motivation & Not specified & Yes & 40 & Chen et al. (2016) \\
\hline No motivation & Not specified & No & 40 & Chong and Wang (2017) \\
\hline No motivation & Not specified & No & Not specified & Cong et al. (2020) \\
\hline No motivation & Not specified & Yes & 1 & Dolci et al. (2020) \\
\hline No motivation & Common design life & No & 80 & Du et al. (2018) \\
\hline No motivation & Assumptions & Yes & $18-20$ & Farina et al. (2017) \\
\hline No motivation & Design service life & No & 150 & García-Segura et al. (2017) \\
\hline No motivation & Not specified & No & $20-75$ & Gregory et al. (2016) \\
\hline No motivation & Assumed average lifetime & No & 20 & Gulotta et al. (2018) \\
\hline No motivation & Assumed lifetime & No & 20 & Gulotta et al. (2019) \\
\hline No motivation & Not specified & No & 100 & Hajiesmaeili et al. (2019) \\
\hline No motivation & Estimated design life & No & 20 & Hamdar et al. (2020) \\
\hline No motivation & Not specified & No & 20 & Hofko et al. (2017) \\
\hline No motivation & "As customary" & No & 40 & Hong and Prozzi (2018) \\
\hline No motivation & Not specified & Yes & 30 & Huang et al. (2018) \\
\hline No motivation & Not specified & No & 50 & Iwase et al. (2020) \\
\hline
\end{tabular}


Table 5 (continued)

\begin{tabular}{|c|c|c|c|c|}
\hline $\begin{array}{l}\text { Approach to determine } \\
\text { length of analysis period }\end{array}$ & Reference to analysis period & $\begin{array}{l}\text { Compare alternatives } \\
\text { with different service } \\
\text { lives }\end{array}$ & Analysis period (years) & Reference \\
\hline No motivation & Assumed & No & 30 & $\begin{array}{l}\text { Lizasoain-Arteaga et al. } \\
\text { (2019) }\end{array}$ \\
\hline No motivation & Not specified & Not specified & Not specified & Lu et al. (2019) \\
\hline No motivation & Design life & No & 15 & Ma et al. (2019) \\
\hline No motivation & Not specified & No & 30 & $\begin{array}{l}\text { Manosalvas-Paredes et al. } \\
(2020)\end{array}$ \\
\hline No motivation & Not specified & No & 50 & Marzouk et al. (2017) \\
\hline No motivation & Not specified & Yes & 35 & Mazumder et al. (2018) \\
\hline No motivation & Not specified & Yes & 40 & O'Born et al. (2016) \\
\hline No motivation & Not specified & No & 100 & Penadés-Plà et al. (2020) \\
\hline No motivation & Assumed & No & 20 & Praticò et al. (2020) \\
\hline No motivation & Not specified & Yes & 100 & Redaelli et al. (2019) \\
\hline No motivation & Not specified & Yes & 45 & Rodríguez-Alloza et al. (2019) \\
\hline No motivation & Not specified & Not specified & Not specified & $\begin{array}{l}\text { Rodríguez-Fernández et al. } \\
\text { (2020) }\end{array}$ \\
\hline No motivation & Not specified & Yes & 50 & Saeedzadeh et al. (2018) \\
\hline No motivation & Not specified & No & 90 & Sameer et al. (2019) \\
\hline No motivation & Not specified & No & 50 & Santos et al. (2017a) \\
\hline No motivation & Not specified & No & 30 & Santos et al. (2018a) \\
\hline No motivation & Not specified & No & 50 & Santos et al. (2018b) \\
\hline No motivation & Not specified & No & 30 & Santos et al. (2019) \\
\hline No motivation & Not specified & No & 30 & Santos et al. (2020) \\
\hline No motivation & Not specified & No & 50 & Santos et al. (2017b) \\
\hline No motivation & Expected life span & No & 50 & Schlegel et al. (2016) \\
\hline No motivation & Approximate lifespan & No & 50 & Setsobhonkul et al. (2017) \\
\hline No motivation & Not specified & Yes & 60 & Stripple et al. (2016) \\
\hline No motivation & Not specified & No & 75 & Tapia and Padgett (2016) \\
\hline No motivation & Not specified & Not specified & Not specified & Tuler and Kaewunruen (2017) \\
\hline No motivation & Not specified & Not specified & Not specified & Vila-Cortavitarte et al. (2018) \\
\hline No motivation & Not specified & No & 50 & Xu et al. (2019) \\
\hline No motivation & Not specified & No & 20 & Zheng et al. (2020) \\
\hline No motivation & Not specified & No & 30 & Zulu et al. (2020) \\
\hline Period of use & Previous studies & Yes & 40 & Noda et al. (2016) \\
\hline Period of use & Construction documents & No & 60 & O'Born (2018) \\
\hline $\begin{array}{l}\text { Service life of adjacent } \\
\text { infrastructure }\end{array}$ & $\begin{array}{l}\text { Average technical life span of } \\
\text { sewer pipes }\end{array}$ & No & 60 & Trigaux et al. (2017) \\
\hline
\end{tabular}


Table 6 Approach used to determine the maintenance frequency in each paper and the references used to estimate maintenance frequency

\begin{tabular}{|c|c|c|}
\hline Approach used to estimate maintenance frequency & Reference to maintenance frequency & Reference \\
\hline Current practice & Expert estimations & Audi et al. (2020) \\
\hline Current practice & Quebec transport government & AzariJafari et al. (2018) \\
\hline Current practice & $\begin{array}{l}\text { Maintenance plans from Florida Department of Trans- } \\
\text { portation }\end{array}$ & Batouli et al. (2017) \\
\hline Current practice & Regular maintenance by the Slovenian Roads Operator & Bizjak and Lenart (2018) \\
\hline Current practice & Regular maintenance by Croatian railways & Bizjak et al. (2017) \\
\hline Current practice & Construction guidelines & Butt and Birgisson (2016) \\
\hline Current practice & Illinois Tollway standards of practice & Byrne et al. (2017) \\
\hline Current practice & Routine maintenance based on previous study & Cantisani et al. (2018) \\
\hline Current practice & Estimations by manufacturer & Cherubini et al. (2019) \\
\hline Current practice & Missouri Department of Transportation & Choi et al. (2016) \\
\hline Current practice & Statistics, experts & Du et al. (2018) \\
\hline Current practice & Chinese regulations & Guo et al. (2019) \\
\hline Current practice & "Currently practiced in the field" & Hasan et al. (2020) \\
\hline Current practice & $\begin{array}{l}\text { LCCA manual from California Department of Trans- } \\
\text { portation }\end{array}$ & Huang et al. (2018) \\
\hline Current practice & $\begin{array}{l}\text { Interviews with design and construction companies and } \\
\text { bridge designers; legal service life of wooden bridges }\end{array}$ & Iwase et al. (2020) \\
\hline Current practice & Design specifications from transport agencies & Krishna and Kumar (2020) \\
\hline Current practice & $\begin{array}{l}\text { Standard maintenance practices in European motorway } \\
\text { administrations }\end{array}$ & Lemma et al. (2020) \\
\hline Current practice & $\begin{array}{l}\text { Specifications of maintenance for asphalt surfaces and } \\
\text { permeable asphalt }\end{array}$ & Liu et al. (2020) \\
\hline Current practice & Various studies, aiming to find the period of use & Noda et al. (2016) \\
\hline Current practice & National road requirements & O'Born et al. (2016) \\
\hline Current practice & Expert estimation by the design company & Peñaloza et al. (2018) \\
\hline Current practice & Representing French practice & Santos et al. (2018a) \\
\hline Current practice & According to French practice & Santos et al. (2019) \\
\hline Current practice & According to French practice & Santos et al. (2020) \\
\hline Current practice & Reference to previous study & Umer et al. (2017) \\
\hline Current practice & $\begin{array}{l}\text { Earlier study referring to Washington State Department } \\
\text { of Transportation policy }\end{array}$ & Wang et al. (2020) \\
\hline Current practice, not possible to determine & National road requirements, assumptions & O'Born (2018) \\
\hline Current practice, laboratory tests & $\begin{array}{l}\text { For the conventional solution: expert estimates. For the } \\
\text { innovative solution: laboratory tests (laboratory pre- } \\
\text { pared specimens and cores from full-scale application) }\end{array}$ & Landi et al. (2020) \\
\hline Current practice, laboratory tests & $\begin{array}{l}\text { For the conventional solution: expert estimates. For } \\
\text { the innovative solution: laboratory tests (the authors } \\
\text { of this review could not trace the method from the } \\
\text { original references) }\end{array}$ & Lizasoain-Arteaga et al. (2019) \\
\hline Current practice, laboratory tests & $\begin{array}{l}\text { Expert assessment and previous studies; laboratory } \\
\text { tests based on embedded sensors applied to the road } \\
\text { surface in a testing facility }\end{array}$ & Manosalvas-Paredes et al. (2020) \\
\hline Current practice, modelling & $\begin{array}{l}\text { Interviews and on-site observations; previous studies } \\
\text { based on a model to forecast maintenance needs on } \\
\text { the track network }\end{array}$ & Krezo et al. (2016) \\
\hline Current practice, modelling & $\begin{array}{l}\text { Reasoning based on a survey (experts) and a literature } \\
\text { review (mix of modelling and monitored test sections) }\end{array}$ & Mazumder et al. (2018) \\
\hline Current practice, scenario & $\begin{array}{l}\text { Italian standards, previous studies, scenarios related to } \\
\text { material performance }\end{array}$ & Dolci et al. (2020) \\
\hline Laboratory tests & $\begin{array}{l}\text { Full-scale application at a road surface testing facility, } \\
\text { cores analysed in laboratory }\end{array}$ & Saeedzadeh et al. (2018) \\
\hline Modelling & Chloride induced corrosion & Al-Ayish et al. (2018) \\
\hline
\end{tabular}


Table 6 (continued)

\begin{tabular}{|c|c|c|}
\hline Approach used to estimate maintenance frequency & Reference to maintenance frequency & Reference \\
\hline Modelling & Performance-predictions by finite element simulations & Balieu et al. (2019) \\
\hline Modelling & $\begin{array}{l}\text { Integrated model (based on laboratory tests) proposed in } \\
\text { previous study }\end{array}$ & Bressi et al. (2018) \\
\hline Modelling & Life-365 software & Cadenazzi et al. (2019) \\
\hline Modelling & Life-365 software & Cadenazzi et al. (2020) \\
\hline Modelling & "ME pavement design guide" software & Chen et al. (2016) \\
\hline Modelling & $\begin{array}{l}\text { Road surface design software from Korea Pavement } \\
\text { Research Program, "Pavement Condition Index" }\end{array}$ & Choi (2019) \\
\hline Modelling & "ME pavement design guide" software & Chong and Wang (2017) \\
\hline Modelling & "ME pavement design guide" software & Chong et al. (2018) \\
\hline Modelling & "Pavement condition index" & Cong et al. (2020) \\
\hline Modelling & Modelling of corrosion propagation & García-Segura et al. (2017) \\
\hline Modelling & "ME pavement design guide" software & Gregory et al. (2016) \\
\hline Modelling & Compare three performance measures & Hamdar et al. (2020) \\
\hline Modelling & $\begin{array}{l}\text { Road surface design software (ME), previous studies } \\
\text { reporting results from observations and laboratory } \\
\text { tests on trial sections }\end{array}$ & Haslett et al. (2019) \\
\hline Modelling & $\begin{array}{l}\text { Including dynamic programming, Monte Carlo analysis, } \\
\text { and TOPSIS to find the best road surface alternative }\end{array}$ & Heidari et al. (2020) \\
\hline Modelling & $\begin{array}{l}\text { Road surface deterioration model developed in a previ- } \\
\text { ous study }\end{array}$ & Hong and Prozzi (2018) \\
\hline Modelling & $\begin{array}{l}\text { Use framework from a previous study which integrates } \\
\text { LCA with a "ME pavement design guide" model }\end{array}$ & Lu et al. (2019) \\
\hline Modelling & $\begin{array}{l}\text { Fickean model (time-dependent evaluation of chloride } \\
\text { concentration in concrete) }\end{array}$ & Navarro et al. (2018) \\
\hline Modelling & $\begin{array}{l}\text { Fickean model (time-dependent evaluation of chloride } \\
\text { concentration in concrete) }\end{array}$ & Navarro et al. (2019a) \\
\hline Modelling & $\begin{array}{l}\text { Fickean model (time-dependent evaluation of chloride } \\
\text { concentration in concrete) }\end{array}$ & Navarro et al. (2019b) \\
\hline Modelling & $\begin{array}{l}\text { Based on the extended fatigue strength curve in } \\
\text { Eurocode EN 1993-1-97.1 }\end{array}$ & Orcesi et al. (2019) \\
\hline Modelling & $\begin{array}{l}\text { Degradation curves (developed in a previous project) for } \\
\text { functional characteristics vs traffic; American Asso- } \\
\text { ciation of State Highway and Transportation Officials } \\
\text { method ("present serviceability index" over time) }\end{array}$ & Puccini et al. (2019) \\
\hline Modelling & $\begin{array}{l}\text { International Federation for Structural Concrete Model } \\
\text { Code for Service Life Design }\end{array}$ & Redaelli et al. (2019) \\
\hline Modelling & Software Alize \& 3D-move & Rodríguez-Fernández et al. (2020) \\
\hline Modelling & $\begin{array}{l}\text { Performance-prediction model from Virginia Depart- } \\
\text { ment of Transportation; optimisation to determine } \\
\text { optimal maintenance schedule }\end{array}$ & Santos et al. (2017a) \\
\hline Modelling & $\begin{array}{l}\text { Performance-prediction model from Virginia Depart- } \\
\text { ment of Transportation; optimisation to maximise } \\
\text { performance }\end{array}$ & Santos et al. (2018b) \\
\hline Modelling & $\begin{array}{l}\text { Relationship between "pavement condition index" and } \\
\text { time; maintenance at a specific "pavement condition } \\
\text { index" }\end{array}$ & Simões et al. (2017) \\
\hline Modelling & $\begin{array}{l}\text { Time-dependent reliability model based on bridge- } \\
\text { investigations; optimisation to find optimal preventive } \\
\text { maintenance schedule }\end{array}$ & Xie et al. (2018) \\
\hline Modelling & "ME pavement design guide" & Xu et al. (2019) \\
\hline Modelling & $\begin{array}{l}\text { "Pavement condition index" and "riding quality index" } \\
\text { over time based on previous studies }\end{array}$ & Zheng et al. (2020) \\
\hline Not possible to determine & A proportion of original surface layer & Boonpoke et al. (2018) \\
\hline
\end{tabular}


Table 6 (continued)

\begin{tabular}{|c|c|c|}
\hline Approach used to estimate maintenance frequency & Reference to maintenance frequency & Reference \\
\hline Not possible to determine & Assumptions & Farina et al. (2017) \\
\hline Not possible to determine & Assumed maintenance plans & Gulotta et al. (2018) \\
\hline Not possible to determine & $\begin{array}{l}\text { The reference provided does not support the mainte- } \\
\text { nance frequency mentioned }\end{array}$ & Gulotta et al. (2019) \\
\hline Not possible to determine & No references provided & Hajiesmaeili et al. (2019) \\
\hline Not possible to determine & No references provided & Hofko et al. (2017) \\
\hline Not possible to determine & Not specified & Marzouk et al. (2017) \\
\hline Not possible to determine & No reference provided & Penadés-Plà et al. (2017) \\
\hline Not possible to determine & $\begin{array}{l}\text { Reference to a previous study that provides no reference } \\
\text { to the maintenance scenario }\end{array}$ & Penadés-Plà et al. (2020) \\
\hline Not possible to determine & $\begin{array}{l}\text { The reference provided does not support the mainte- } \\
\text { nance frequency mentioned }\end{array}$ & Praticò et al. (2020) \\
\hline Not possible to determine & No reference provided & Rodrigues et al. (2017) \\
\hline Not possible to determine & No reference provided & Rodríguez-Alloza et al. (2019) \\
\hline Not possible to determine & Reference could not be accessed & Sameer et al. (2019) \\
\hline Not possible to determine & Previous studies that could not be accessed & Setsobhonkul et al. (2017) \\
\hline Not possible to determine & Estimated maintenance frequency & Stripple et al. (2016) \\
\hline Not possible to determine & $\begin{array}{l}\text { Reference to previous study that in turn includes an } \\
\text { assumed maintenance frequency }\end{array}$ & Tapia and Padgett (2016) \\
\hline Not possible to determine & Reference could not be accessed & Trigaux et al. (2017) \\
\hline Not possible to determine & $\begin{array}{l}\text { References to previous studies that could not be } \\
\text { accessed }\end{array}$ & Tuler and Kaewunruen (2017) \\
\hline Not possible to determine & Not specified & Vila-Cortavitarte et al. (2018) \\
\hline Not possible to determine & No reference provided & Yeon et al. (2020) \\
\hline Not possible to determine & No reference provided & Zulu et al. (2020) \\
\hline Not possible to determine, current practice & $\begin{array}{l}\text { For some materials, reference could not be accessed or } \\
\text { assumptions were made; for other materials references } \\
\text { to previous studies based on expert assessments }\end{array}$ & Schlegel et al. (2016) \\
\hline Scenario & Scenarios based on maintenance budget & Celauro et al. (2017) \\
\hline Scenario & Scenarios based on maintenance budget & Mauro and Guerrieri (2016) \\
\hline Scenario & $\begin{array}{l}\text { Network Rail Vehicle and Track Interaction Strategic } \\
\text { Model based on observations from UK routes; sce- } \\
\text { nario based on traffic load }\end{array}$ & Rempelos et al. (2020) \\
\hline Scenario & $\begin{array}{l}\text { Scenarios based on maintenance practices: current } \\
\text { practice vs preventive maintenance }\end{array}$ & Santos et al. (2017b) \\
\hline Scenario, modelling & $\begin{array}{l}\text { Scenarios based on maintenance budget for the asphalt; } \\
\text { crash probability for the crash barrier }\end{array}$ & Guerrieri et al. (2020) \\
\hline Scenario, modelling & $\begin{array}{l}\text { "Pavement condition index" deteriorating model; sce- } \\
\text { narios based on material performance }\end{array}$ & Ma et al. (2019) \\
\hline
\end{tabular}

Acknowledgements This paper was produced as part of the Mistra InfraMaint research programme with funding from Mistra, the Swedish Foundation for Strategic Environmental Research.

Funding Open access funding provided by Royal Institute of Technology.

Open Access This article is licensed under a Creative Commons Attribution 4.0 International License, which permits use, sharing, adaptation, distribution and reproduction in any medium or format, as long as you give appropriate credit to the original author(s) and the source, provide a link to the Creative Commons licence, and indicate if changes were made. The images or other third party material in this article are included in the article's Creative Commons licence, unless indicated otherwise in a credit line to the material. If material is not included in the article's Creative Commons licence and your intended use is not permitted by statutory regulation or exceeds the permitted use, you will need to obtain permission directly from the copyright holder. To view a copy of this licence, visit http://creativecommons.org/licenses/by/4.0/.

\section{References}

Al-Ayish N, During O, Malaga K, Silva N, Gudmundsson K (2018) The influence of supplementary cementitious materials on climate impact of concrete bridges exposed to chlorides. Constr 
Build Mater 188:391-398. https://doi.org/10.1016/j.conbuildmat. 2018.08.132

Anthonissen J, Van den bergh W, Braet J (2016) Review and environmental impact assessment of green technologies for base courses in bituminous pavements. Environ Impact Assess Rev 60:139-147. https://doi.org/10.1016/j.eiar.2016.04.005

Arent DJ, Tol RSJ, Faust E, Hella JP, Kumar S, Strzepek KM, Tóth FL, Yan D (2014) Key economic sectors and services. In: Field CB, Barros VR, Dokken DJ, Mach KJ, Mastrandrea MD, Bilir TE, Chatterjee M, Ebi KL, Estrada YO, Genova RC, Girma B, Kissel ES, Levy AN, MacCracken S, Mastrandrea PR, White LL (eds) Climate Change 2014: Impacts, Adaptation, and Vulnerability. Part A: Global and Sectoral Aspects. Contribution of Working Group II to the Fifth Assessment Report of the Intergovernmental Panel on Climate Change. Cambridge University Press, Cambridge, United Kingdom and New York, NY, USA, pp 659-708

Audi Y, Jullien A, Dauvergne M, Feraille A, D’Aloia Schwartzentruber L (2020) Methodology and application for the environmental assessment of underground multimodal tunnels. Transp Geotech 24:100389. https://doi.org/10.1016/j.trgeo.2020.100389

AzariJafari H, Yahia A, Amor MB (2016) Life cycle assessment of pavements: reviewing research challenges and opportunities. J Clean Prod 112:2187-2197. https://doi.org/10.1016/j.jclepro. 2015.09.080

AzariJafari H, Yahia A, Amor B (2018) Assessing the individual and combined effects of uncertainty and variability sources in comparative LCA of pavements. Int J Life Cycle Assess 23:18881902. https://doi.org/10.1007/s11367-017-1400-1

Balieu R, Chen F, Kringos N (2019) Life cycle sustainability assessment of electrified road systems. Road Mater Pavement Des 20(S1):19-33. https://doi.org/10.1080/14680629.2019.1588771

Batouli M, Bienvenu M, Mostafavi A (2017) Putting sustainability theory into roadway design practice: Implementation of LCA and LCCA analysis for pavement type selection in real world decision making. Transp Res D Transp Environ 52:289-302. https://doi. org/10.1016/j.trd.2017.02.018

Bizjak KF, Knez F, Lenart S, Slanc K (2017) Life-cycle assessment and repair of the railway transition zones of an existing bridge using geocomposite materials. Struct Infrastruct Eng 13(3):331-344. https://doi.org/10.1080/15732479.2016.1158288

Bizjak KF, Lenart S (2018) Life cycle assessment of a geosyntheticreinforced soil bridge system - A case study. Geotext Geomembr 46:543-558. https://doi.org/10.1016/j.geotexmem.2018.04.012

Boonpoke A, Sriburee J, Sedpho S, Prasertsang T (2018) Environmental impact evaluation of road pavements using life cycle assessment tool. Lowl Technol Int 20(2):117-124

Bressi S, D’Angelo G, Santos J, Giunta M (2018) Environmental performance analysis of bitumen stabilized ballast for railway trackbed using life-cycle assessment. Constr Build Mater 188:10501064. https://doi.org/10.1016/j.conbuildmat.2018.08.175

Butt AA, Toller S, Birgisson B (2015) Life cycle assessment for the green procurement of roads: a way forward. J Clean Prod 90:163-170. https://doi.org/10.1016/j.jclepro.2014.11.068

Butt AA, Birgisson B (2016) Assessment of the attributes based life cycle assessment framework for road projects. Struct Infrastruct Eng 12(9):1177-1184. https://doi.org/10.1080/15732479.2015. 1086388

Byrne DM, Grabowski MK, Benitez ACB, Schmidt AR, Guest JS (2017) Evaluation of life cycle assessment (LCA) for roadway drainage systems. Environ Sci Technol 51:9261-9270. https:// doi.org/10.1021/acs.est.7b01856

Cadenazzi T, Dotelli G, Rossini M, Nolan S, Nanni A (2019) Lifecycle cost and life-cycle assessment analysis at the design stage of a fiber-reinforced polymer-reinforced concrete bridge in Florida. Adv Civ Eng Mater 8(2):ACEM20180113. https:// doi.org/10.1520/ACEM20180113
Cadenazzi T, Dotelli G, Rossini M, Nolan S, Nanni A (2020) Cost and environmental analyses of reinforcement alternatives for a concrete bridge. Struct Infrastruct Eng 16(4):787-802. https:// doi.org/10.1080/15732479.2019.1662066

Cantisani G, Di Mascio P, Moretti L (2018) Comparative life cycle assessment of lighting systems and road pavements in an Italian twin-tube road tunnel. Sust 10. https://doi.org/10.3390/ su 10114165

Celauro C, Corriere F, Guerrieri M, Casto BL, Rizzo A (2017) Environmental analysis of different construction techniques and maintenance activities for a typical local road. J Clean Prod 142:3482-3489. https://doi.org/10.1016/j.jclepro.2016.10.119

Chen F, Zhu H, Yu B, Wang H (2016) Environmental burdens of regular and long-term pavement designs: a life cycle view. Int J Pavement Eng 17(4):300-313. https://doi.org/10.1080/10298436.2014. 993189

Cherubini E, Zanghelini GM, Piemonte D, Muller NB, Dias R, Kabe YHO, Soto J (2019) Environmental sustainability for highways operation: Comparative analysis of plastic and steel screen anti-glare systems. J Clean Prod 240:118152. https://doi.org/ 10.1016/j.jclepro.2019.118152

Choi K, Lee HW, Mao Z, Lavy S, Ryoo BY (2016) Environmental, economic, and social implications of highway concrete rehabilitation alternatives. J Constr Eng Manag 142(2):04015079. https://doi. org/10.1061/(ASCE)CO.1943-7862.0001063

Choi J (2019) Strategy for reducing carbon dioxide emissions from maintenance and rehabilitation of highway pavement. J Clean Prod 209:88-100. https://doi.org/10.1016/j.jclepro.2018.10.226

Chong D, Wang Y (2017) Impacts of flexible pavement design and management decisions on life cycle energy consumption and carbon footprint. Int J Life Cycle Assess 22:952-971. https:// doi.org/10.1007/s11367-016-1202-x

Chong D, Wang Y, Dai Z, Chen X, Wang D, Oeser M (2018) Multiobjective optimization of asphalt pavement design and maintenance decisions based on sustainability principles and mechanisticempirical pavement analysis. Int J Sust Transp 12(6):461-472. https://doi.org/10.1080/15568318.2017.1392657

Cong L, Guo G, Yu M, Yang F, Tan L (2020) The energy consumption and emission of polyurethane pavement construction based on life cycle assessment. J Clean Prod 256:120395. https://doi.org/ 10.1016/j.jclepro.2020.120395

Dolci G, Rigamonti L, Grosso M (2020) Potential for improving the environmental performance of railway sleepers with an outer shell made of recycled materials. Transp Res Interdiscip Perspect 6:100160. https://doi.org/10.1016/j.trip.2020.100160

Du G, Pettersson L, Karoumi R (2018) Soil-steel composite bridge: an alternative design solution for short spans considering LCA. J Clean Prod 189:647-661. https://doi.org/10.1016/j.jclepro. 2018.04.097

Farina A, Zanetti MC, Santagata E, Blengini GA (2017) Life cycle assessment applied to bituminous mixtures containing recycled materials: Crumb rubber and reclaimed asphalt pavement. Resour Conserv Recycl 117:204-212. https://doi.org/ 10.1016/j.resconrec.2016.10.015

Future Cities Canada (2018) Building Canada's low-carbon approach to infrastructure investments through prioritization, policy and procurement. https://futurecitiescanada.ca/downloads/ 2018/FCC_ProcurementReport_201809.pdf. Accessed 20 Oct 2020

García-Segura T, Yepes V, Frangopol DM, Yang DY (2017) Lifetime reliability-based optimization of post-tensioned box-girder bridges. Eng Struct 145:381-391. https://doi.org/10.1016/j. engstruct.2017.05.013

Gregory JR, Noshadravan A, Olivetti EA, Kirchain RE (2016) A methodology for robust comparative life cycle assessments 
incorporating uncertainty. Environ Sci Technol 50:6397-6405. https://doi.org/10.1021/acs.est.5b04969

Guerrieri M, Casto BML, Peri G, Rizzo G (2020) Smart vs conventional motorways: Environmental impact assessment under realistic traffic conditions. Sci Total Environ 727:138521. https://doi. org/10.1016/j.scitotenv.2020.138521

Guest G, Zhang J, Maadani O, Shirkhani H (2020) Incorporating the impacts of climate change into infrastructure life cycle assessments - A case study of pavement service life performance. J Ind Ecol 24:356-368. https://doi.org/10.1111/jiec.12915

Gulotta TM, Mistretta M, Praticò FG (2018) Life cycle assessment of roads: material and process related energy savings. Model Measure Control C 79(3):146-153. https://doi.org/10.18280/ mmc_c.790313

Gulotta TM, Mistretta M, Praticò FG (2019) A life cycle scenario analysis of different pavement technologies for urban roads. Sci Total Environ 673:585-593. https://doi.org/10.1016/j.scitotenv. 2019.04.046

Guo C, Xu J, Yang L, Guo X, Liao J, Zheng X, Zhang Z, Chen X, Yang K, Wang M (2019) Life cycle evaluation of greenhouse gas emissions of a highway tunnel: A case study in China. J Clean Prod 211:972-980. https://doi.org/10.1016/j.jclepro.2018.11.249

Hajiesmaeili A, Pittau F, Denarié E, Habert G (2019) Life cycle analysis of strengthening existing RC structures with R-PE-UHPFRC. Sust 11:6923. https://doi.org/10.3390/su11246923

Hamdar Y, Chehab GR, Srour I (2016) Life-cycle evaluation of pavements: A critical review. J Eng Sci Technol Rev 9(6):12-26. https://doi.org/10.25103/jestr.096.02

Hamdar YS, Kassem HA, Chehab GR (2020) Using different performance measures for the sustainability assessment of asphalt mixtures: case of warm mix asphalt in a hot climate. Road Mater Pavement Des 21(1):1-24. https://doi.org/10.1080/14680629. 2018.1474795

Hasan U, Whyte A, Al Jassmi H (2020) Life cycle assessment of roadworks in United Arab Emirates: Recycled construction waste, reclaimed asphalt pavement, warm-mix asphalt and blast furnace slag use against traditional approach. J Clean Prod 257:120531. https://doi.org/10.1016/j.jclepro.2020.120531

Haslett KE, Dave EV, Mo W (2019) Realistic traffic condition informed life cycle assessment: interstate 495 maintenance and rehabilitation case study. Sust 11(12):3245. https://doi.org/10.3390/su11123245

Heidari MR, Heravi G, Esmaeeli AN (2020) Integrating life-cycle assessment and life-cycle cost analysis to select sustainable pavement: A probabilistic model using managerial flexibilities. J Clean Prod 254:120046. https://doi.org/10.1016/j.jclepro.2020.120046

Hofko B, Dimitrov M, Schwab O, Weiss F, Rechberger H, Grothe H (2017) Technological and environmental performance of temperaturereduced mastic asphalt mixtures. Road Mater Pavement Des 18(1):22-37. https://doi.org/10.1080/14680629.2016.1141703

Höjer M, Ahlroth S, Dreborg K-H, Ekvall T, Finnveden G, Hjelm O, Hochschorner E, Nilsson M, Palm V (2008) Scenarios in selected tools for environmental systems analysis. J Clean Prod 16:19581970. https://doi.org/10.1016/j.jclepro.2008.01.008

Hong F, Prozzi JA (2018) Evaluation of recycled asphalt pavement using economic, environmental, and energy metrics based on long-term pavement performance sections. Road Mater Pavement Des 19(8):1816-1831. https://doi.org/10.1080/14680629. 2017.1348306

Huang J, Xiao F, Zhang Y (2018) Reliability evaluation of pavement life-cycle assessment model. Model Simul Eng 2018:172519. https://doi.org/10.1155/2018/4172519

Inyim P, Pereyra J, Bienvenu M, Mostafavi A (2016) Environmental assessment of pavement infrastructure: A systematic review. J Environ Manag 176:128-138. https://doi.org/10.1016/j.jenvman. 2016.03.042
Iwase T, Sasaki T, Araki S, Huzita T, Kayo C (2020) Environmental and economic evaluation of small-scale bridge repair using crosslaminated timber floor slabs. Sust 12(8):3424. https://doi.org/10. 3390/su12083424

Jiang R, Wu P (2019) Estimation of environmental impacts of roads through life cycle assessment: A critical review and future directions. Transp Res D Transp Environ 77:148-163. https://doi.org/ 10.1016/j.trd.2019.10.010

Keijzer EE, Leegwater GA, de Vos-Effting SE, de Wit MS (2015) Carbon footprint comparison of innovative techniques in the construction and maintenance of road infrastructure in the Netherlands. Envir Sci Policy 54:218-225. https://doi.org/10. 1016/j.envsci.2015.06.010

Krezo S, Mirza O, He Y, Makim P, Kaewunruen S (2016) Field investigation and parametric study of greenhouse gas emissions from railway plain-line renewals. Transp Res D Transp Environ 42:77-90. https://doi.org/10.1016/j.trd.2015.10.021

Krishna USR, Kumar CNS (2020) A case study on maintenance of bituminous concrete pavement considering life cycle cost analysis and carbon footprint estimation. Int J Constr Manag, in Press. https://doi.org/10.1080/15623599.2020.1742629

Landi D, Marconi M, Bocci E, Germani M (2020) Comparative life cycle assessment of standard, cellulose-reinforced and end of life tires fiber-reinforced hot mix asphalt mixtures. J Clean Prod 248:119295. https://doi.org/10.1016/j.jclepro.2019.119295

Lemma MS, Gervásio H, Pedro JO, Rigueiro C, da Silva LS (2020) Enhancement of the life-cycle performance of bridges using high-strength steel. Struct Infrastruct Eng 16(4):772-786. https:// doi.org/10.1080/15732479.2019.1662067

Liljenström C, Toller S, Åkerman J, Björklund A (2019) Annual climate impact and primary energy use of Swedish transport infrastructure. Eur J Transp Infrastruct Res 19(2):77-116. https://doi. org/10.18757/ejtir.2019.19.2.4378

Liu J, Li H, Wang Y, Zhang H (2020) Integrated life cycle assessment of permeable pavement: Model development and case study. Transp Res D Transp Environ 85:102381. https://doi.org/10. 1016/j.trd.2020.102381

Lizasoain-Arteaga E, Indacoechea-Vega I, Pascual-Muñoz P, CastroFresno D (2019) Environmental impact assessment of inductionhealed asphalt mixtures. J Clean Prod 208:1546-1556. https:// doi.org/10.1016/j.jclepro.2018.10.223

Lu G, Wang Y, Li H, Wang D, Oeser M (2019) The environmental impact evaluation on the application of permeable pavement based on life cycle analysis. Int J Transp Sci Technol 8:351-357. https://doi.org/10.1016/j.ijtst.2019.05.006

Ma H, Zhang Z, Zhao X, Wu S (2019) A comparative life cycle assessment (LCA) of warm mix asphalt (WMA) and hot mix asphalt (HMA) pavement: A case study in China. Adv Civ Eng 2019:9391857. https://doi.org/10.1155/2019/9391857

Manosalvas-Paredes M, Roberts R, Barriera M, Mantalovas K (2020) Towards more sustainable pavement management practices using embedded sensor technologies. Infrastruct 5(1). https://doi.org/ 10.3390/infrastructures5010004

Marzouk M, Abdelkader EM, El-zayat M, Aboushady A (2017) Assessing environmental impact indicators in road construction projects in developing countries. Sust 9(5):843. https://doi.org/ $10.3390 / \mathrm{su} 9050843$

Mauro R, Guerrieri M (2016) Comparative life-cycle assessment of conventional (double lane) and non-conventional (turbo and flower) roundabout intersections. Transp Res D Transp Environ 48:96-111. https://doi.org/10.1016/j.trd.2016.08.011

Mazumder M, Sriraman V, Kim HH, Lee S-J (2018) Quantifying the environmental impacts of crack sealing and filling treatment in hot mix asphalt pavement. Innov Infrastruct Solut 3:61. https:// doi.org/10.1007/s41062-018-0161-4 
Navarro IJ, Yepes V, Martí JV, González-Vidosa F (2018) Life cycle impact assessment of corrosion preventive designs applied to prestressed concrete bridge decks. J Clean Prod 196:698-713. https://doi.org/10.1016/j.jclepro.2018.06.110

Navarro IJ, Martí JV, Yepes V (2019a) Reliability-based maintenance optimization of corrosion preventive designs under a life cycle perspective. Environ Impact Assess Rev 74:23-34. https://doi. org/10.1016/j.eiar.2018.10.001

Navarro IJ, Yepes V, Martí JV (2019b) Sustainability assessment of concrete bridge deck designs in coastal environments using neutrosophic criteria weights. Struct Infrastruct Eng 16(7):949-967. https://doi.org/10.1080/15732479.2019.1676791

Noda R, Kayo C, Yamanouchi M, Shibata N (2016) Life cycle greenhouse gas emission of wooden guardrails: a study in Nagano Prefecture. J Wood Sci 62:181-193. https://doi.org/10.1007/ s10086-015-1530-7

O'Born R, Brattebø H, Iversen OMK, Miliutenko S, Potting J (2016) Quantifying energy demand and greenhouse gas emissions of road infrastructure projects: An LCA case study of the Oslo fjord crossing in Norway. Eur J Transp Infrastruct Res 16(3):445-466. https://doi.org/10.18757/ejtir.2016.16.3.3152

O’Born R (2018) Life cycle assessment of large scale timber bridges: A case study from the world's longest timber bridge design in Norway. Transp Res D Transp Environ 59:301-312. https://doi. org/10.1016/j.trd.2018.01.018

Olugbenga O, Kalyviotis N, Saxe S (2019) Embodied emissions in rail infrastructure: a critical literature review. Environ Res Lett 14(12):123002. https://doi.org/10.1088/1748-9326/ab442f

Orcesi AD, Feraille A, Chataigner S (2019) Fatigue strengthening of steel structures using high modulus CFRP plates: Development of a life-cycle analysis approach. Constr Build Mater 227:116628. https://doi.org/10.1016/j.conbuildmat.2019.08.009

Penadés-Plà V, Martí JV, García-Segura T, Yepes V (2017) Life-cycle assessment: a comparison between two optimal post-tensioned concrete box-girder road bridges. Sust 9(10):1864. https://doi. org/10.3390/su9101864

Penadés-Plà V, Yepes V, García-Segura T (2020) Robust decisionmaking design for sustainable pedestrian concrete bridges. Eng Struct 209:109968. https://doi.org/10.1016/j.engstruct.2019. 109968

Peñaloza D, Erlandsson M, Pousette A (2018) Climate impacts from road bridges: effects of introducing concrete carbonation and biogenic carbon storage in wood. Struct Infrastruct Eng 14(1):5667. https://doi.org/10.1080/15732479.2017.1327545

Praticò FG, Giunta M, Mistretta M, Gulotta TM (2020) Energy and environmental life cycle assessment of sustainable pavement materials and technologies for urban roads. Sust 12:704. https:// doi.org/10.3390/su12020704

Puccini M, Leandri P, Tasca AL, Pistonesi L, Losa M (2019) Improving the environmental sustainability of low noise pavements: comparative life cycle assessment of reclaimed asphalt and crumb rubber based warm mix technologies. Coat 9(5):343. https://doi. org/10.3390/coatings9050343

Qiao Y, Dawson AR, Parry T, Flintsch G, Wang W (2020) Flexible pavements and climate change: A comprehensive review and implications. Sust 12(3):1057. https://doi.org/10.3390/su12031057

Redaelli E, Arrigoni A, Carsana M, Dotelli G, Gastaldi M, Lollini F, Bertola F, Canonico F, Nanni A (2019) Culvert prototype made with seawater concrete: materials characterization, monitoring, and environmental impact. Adv Civ Eng Mater 8(2). https://doi. org/10.1520/ACEM20180114

Rempelos G, Preston J, Blainey S (2020) A carbon footprint analysis of railway sleepers in the United Kingdom. Transp Res D Transp Environ 81:102285. https://doi.org/10.1016/j.trd.2020.102285

Rodrigues JN, Providência P, Dias AMPG (2017) Sustainability and lifecycle assessment of timber-concrete composite bridges. J
Infrastruct Syst 23(1):04016025. https://doi.org/10.1061/(ASCE) IS.1943-555X.0000310

Rodríguez-Alloza AM, Heihsel M, Fry J, Gallego J, Geschke A, Wood R, Lenzen M (2019) Consequences of long-term infrastructure decisions? The case of self-healing roads and their $\mathrm{CO}_{2}$ emissions. Environ Res Lett 14:114040. https://doi.org/10.1088/ 1748-9326/ab424a

Rodríguez-Fernández I, Lizasoain-Arteaga E, Lastra-González P, Castro-Fresno D (2020) Mechanical, environmental and economic feasibility of highly sustainable porous asphalt mixtures. Constr Build Mater 251:118982. https://doi.org/10.1016/j. conbuildmat.2020.118982

Saeedzadeh R, Romanoschi SA, Akbariyeh N, Khajeh-Hosseini M, Abdullah AQ (2018) Sustainability assessment of recycled asphalt mixtures based on performance in full-scale testing. J Transp Eng B 144(2):04018024. https://doi.org/10.1061/JPEODX.0000048

Sameer H, Weber V, Mostert C, Bringezu S, Fehling E, Wetzel A (2019) Environmental assessment of ultra-high-performance concrete using carbon, material, and water footprint. Mater 12(6):851. https://doi.org/10.3390/ma12060851

Santero NJ, Masanet E, Horvath A (2011a) Life-cycle assessment of pavements. Part I: Critical review. Resour Conserv Recycl 55:801-809. https://doi.org/10.1016/j.resconrec.2011.03.010

Santero N, Loijos A, Akbarian M, Ochsendorf J (2011b) Methods, impacts, and opportunities in the concrete pavement life cycle. http://s3.specifyconcrete.org/doc/MIT_Pavement_LCA_Report. pdf. Accessed 20 Oct 2021

Santos J, Ferreira A, Flintsch G (2017a) A multi-objective optimizationbased pavement management decision-support system for enhancing pavement sustainability. J Clean Prod 164:1380-1393. https://doi.org/10.1016/j.jclepro.2017.07.027

Santos J, Flintsch G, Ferreira A (2017b) Environmental and economic assessment of pavement construction and management practices for enhancing pavement sustainability. Resour Conserv Recycl 116:15-31. https://doi.org/10.1016/j.resconrec.2016.08.025

Santos J, Bressi S, Cerezo V, Presti DL, Dauvergne M (2018a) Life cycle assessment of low temperature asphalt mixtures for road pavement surfaces: a comparative analysis. Resour Conserv Recycl 138:283-297. https://doi.org/10.1016/j.resconrec.2018. 07.012

Santos J, Ferreira A, Flintsch G, Cerezo V (2018b) A multi-objective optimisation approach for sustainable pavement management. Struct Infrastruct Eng 14(7):854-868. https://doi.org/10.1080/ 15732479.2018.1436571

Santos J, Bressi S, Cerezo V, Presti LD (2019) SUP\&R DSS: a sustainability-based decision support system for road pavements. J Clean Prod 206:524-540. https://doi.org/10.1016/j.jclepro.2018. 08.308

Santos J, Torres-Machi C, Morillas S, Cerezo V (2020) A fuzzy logic expert system for selecting optimal and sustainable life cycle maintenance and rehabilitation strategies for road pavements. Int J Pavement Eng, in Press. https://doi.org/10.1080/10298436. 2020.1751161

Saxe S, Kasraian D (2020) Rethinking environmental LCA life stages for transport infrastructure to facilitate holistic assessment. J Ind Ecol 24(5):1031-1046. https://doi.org/10.1111/jiec.13010

Schlegel T, Puiatti D, Ritter H-J, Lesueur D, Denayer C, Shtiza A (2016) The limits of partial life cycle assessment studies in road construction practices: A case study on the use of hydrated lime in Hot Mix Asphalt. Transp Res D Transp Environ 48:141-160. https://doi.org/10.1016/j.trd.2016.08.005

Setsobhonkul S, Kaewunruen S, Sussman JM (2017) Lifecycle assessments of railway bridge transitions exposed to extreme climate events. Front Built Environ 3(35). https://doi.org/10.3389/fbuil. 2017.00035 
Simões D, Almeida-Costa A, Benta A (2017) Preventive maintenance of road pavement with microsurfacing-an economic and sustainable strategy. Int J Sust Transp 11(9):670-680. https://doi. org/10.1080/15568318.2017.1302023

Stripple H, Boström L, Ellison T, Ewertson C, Lund P, Melander R (2016) Evaluation of two different drainage systems for rock tunnels. Tunn Undergr Space Technol 58:40-48. https://doi.org/10. 1016/j.tust.2016.03.015

Tapia C, Padgett JE (2016) Multi-objective optimisation of bridge retrofit and post-event repair selection to enhance sustainability. Struct Infrastruct Eng 12(1):93-107. https://doi.org/10.1080/ 15732479.2014 .995676

Toller S, Larsson M (2017) Implementation of life cycle thinking in planning and procurement at the Swedish Transport Administration. In: Al-Quadi O, Harvey J (eds) Pavement Life-Cycle Assessment. Taylor \& Francis Group, London, pp 281-287

Trigaux D, Wijnants L, De Troyer F, Allacker K (2017) Life cycle assessment and life cycle costing of road infrastructure in residential neighbourhoods. Int J Life Cycle Assess 22:938-951. https://doi.org/10.1007/s11367-016-1190-x

Tuler MV, Kaewunruen S (2017) Life cycle analysis of mitigation methodologies for railway rolling noise and groundbourne vibration. J Environ Manag 191:75-82. https://doi.org/10.1016/j. jenvman.2016.12.075

Umer A, Hewage K, Haider H, Sadiq R (2017) Sustainability evaluation framework for pavement technologies: An integrated life cycle economic and environmental trade-off analysis. Transp Res D Transp Environ 53:88-101. https://doi.org/10.1016/j.trd.2017. 04.011

Valle O, Qiao Y, Dave E, Mo W (2017) Life cycle assessment of pavements under a changing climate. In: Al-Quadi O, Harvey J (eds) Pavement Life-Cycle Assessment. Taylor \& Francis Group, London, pp 241-250
Vila-Cortavitarte M, Lastra-González P, Calzada-Pérez MÁ, Indacoechea-Vega I (2018) Analysis of the influence of using recycled polystyrene as a substitute for bitumen in the behaviour of asphalt concrete mixtures. J Clean Prod 170:1279-1287. https://doi.org/ 10.1016/j.jclepro.2017.09.232

Wang Z, Yang DY, Frangopol DM, Jin W (2020) Inclusion of environmental impacts in life-cycle cost analysis of bridge structures. Sust Resil Infrastruct 5(4):252-267. https://doi.org/10.1080/ 23789689.2018.1542212

Xie H-B, Wu W-J, Wang Y-F (2018) Life-time reliability based optimization of bridge maintenance strategy considering LCA and LCC. J Clean Prod 176:36-45. https://doi.org/10.1016/j.jclepro. 2017.12.123

Xu X, Akbarian M, Gregory J, Kirchain R (2019) Role of the use phase and pavement-vehicle interaction in comparative pavement life cycle assessment as a function of context. J Clean Prod 230:1156-1164. https://doi.org/10.1016/j.jclepro.2019.05.009

Yeon J, Rew Y, Choi K, Kang J (2020) Environmental effects of accelerated pavement repair using 3D printing: life cycle assessment approach. J Manag Eng 36(3):04020003. https://doi.org/10.1061/ (ASCE)ME.1943-5479.0000752

Zheng X, Easa SM, Ji T, Jiang Z (2020) Incorporating uncertainty into life-cycle sustainability assessment of pavement alternatives. J Clean Prod 264:121466. https://doi.org/10.1016/j.jclepro.2020. 121466

Zulu K, Singh RP, Shaba FA (2020) Environmental and economic analysis of selected pavement preservation treatments. Civ Eng J 6(2):210-224. https://doi.org/10.28991/cej-2020-03091465

Publisher's Note Springer Nature remains neutral with regard to jurisdictional claims in published maps and institutional affiliations. 